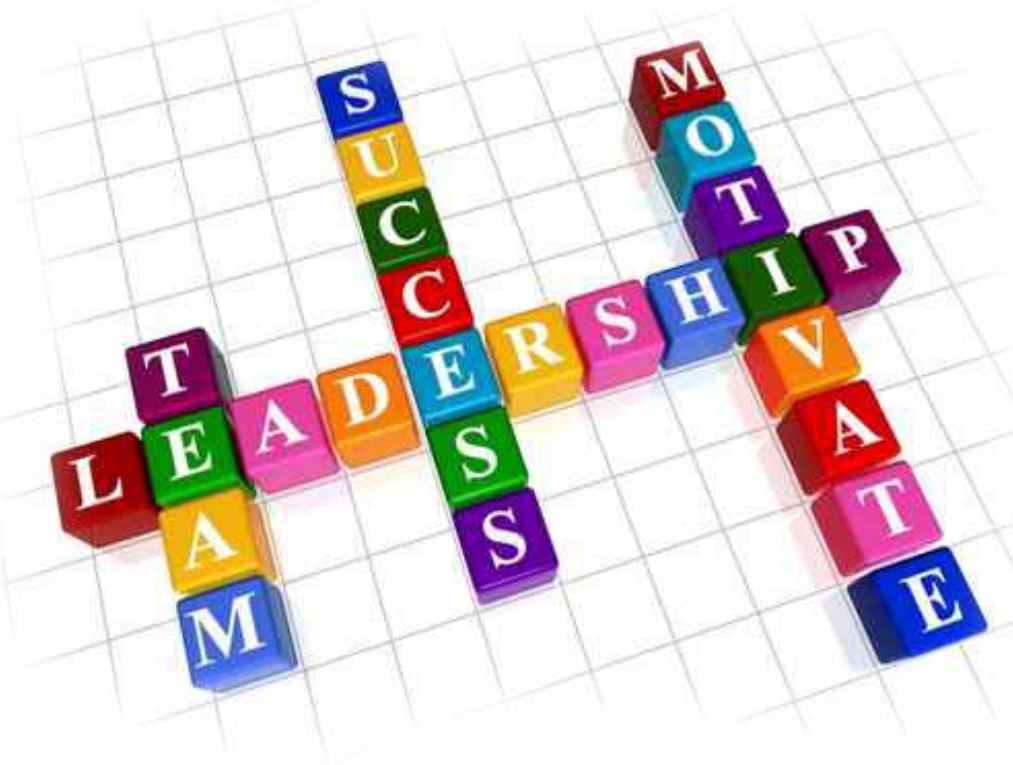

The effect of leader emotional intelligence on leader-follower chemistry

A study of construction project managers
Stephen Pryke, Damir Lunic and Sulafa Badi*

The Bartlett, School of Construction and Project Management

University College London (UCL)

1-19 Torrington Place, London, WC1E 6BT Stephen Pryke: s.pryke@ucl.ac.uk Damir Lunic: lunicdamir@yahoo.com Sulafa Badi: s.badi@ucl.ac.uk

*Corresponding author

Published in Construction Management and Economics 


\section{The effect of leader emotional intelligence on leader-follower chemistry: A study of construction project managers}

1. ABSTRACT

Extending Nicolini's (2002) notion of project 'chemistry', this paper proposes the development of a 'leader-follower chemistry' model associated with the quality of dyadic interpersonal communication in construction projects. The paper focuses on the project manager as leader and attempts to deepen understanding of the effect of a project manager's Emotional Intelligence (EI) on the quality of interpersonal communication with their followers- being other members of the project team. While a project manager's EI, with its associated emotional competencies, is often seen as critical in achieving good relationships with members of the project team, it remains a largely understudied concept, particularly in construction projects. Primary data collected using a series of analytical surveys and live observations of site-based projects meetings were used to examine the relationship between a project manager's emotional competencies, particularly sensitivity and expressiveness, and leaderfollower chemistry. Overall, 68 construction professionals participated in the study. The findings suggest that a project manager's emotional sensitivity and expressiveness (particularly head gestures) may explain variance in the quality of leader-follower chemistry. Based on the empirical evidence in the context of team communication, a leader-follower chemistry model is introduced, which emphasises the importance of leaders' emotional sensitivity and expressiveness in a leader-follower communication dyad. The model may be particularly salient in complex project networks with a large number of prominent actors.

Key words: Project Manager; specific emotional ability approaches; sensitivity; expressiveness; leader-follower chemistry; construction sector. 


\section{INTRODUCTION}

Within the construction industry domain, the drive towards more innovative procurement and business practices such as partnering, Pubic Private Partnerships (PPPs), and Supply Chain management (SCM) underlines the need for more collaborative and non-adversarial attitudes among actors of the project coalition (Egan, 1998; Pryke and Smyth, 2006), and places quality of leadership and interpersonal relationships high on the agenda (Nicolini, 2002, Lloyd-Walker and Walker, 2011). The importance of relationships in construction projects concerning successful project performance was raised by Nicolini's (2002) notion of 'project chemistry'. Nicolini describes project chemistry as "a quality of interaction between people on a project" (Nicolini, 2002: 167). In his work, Nicolini provides some valuable insights into social and relational issues on the success of construction projects and points to the quality of leadership as a critical factor in achieving good project chemistry.

The purpose of the present study is to extend the work of Nicolini (2002) on 'project chemistry' by introducing the concept of 'leader-follower chemistry' as a way of increasing understanding of the competencies needed for leaders to build good quality interactions with their followers in construction projects. As Clarke (2010) argues, projects are inherently 'emotional' and leaders are often considered as the "managers of group emotion"' (Pescosolido, 2002). Indeed, Clarke (2010, p. 605) maintains that relationships within construction project are constructed through social interactions that are fundamentally emotional, and thus, "emotions are likely to play a major role in influencing both the development and trajectory of relationships within project settings". However, there remains a paucity of research on the impact of emotions on projects (Clarke, 2010).

On the other hand, a growing body of research on leadership - both in the general leadership literature as well as in specialist project management literature - stresses the importance of so-called 'Emotional Intelligence' (EI hereafter) on building good relationships between leaders and their followers. Studies of EI underline the significance of two core emotional abilities: emotional sensitivity (the ability to accurately perceive emotions) and emotional expressiveness (the ability to express 
emotions) as essential components of successful leadership (Riggio and Reichard, 2008; Elfenbein and Eisenkraft, 2010; Ashkanasy and Humphrey, 2011; Mast et al., 2012). These 'nonverbal' competencies are seen to help develop the notion of rapport between the leader and follower. In their early study of intergroup processes, TickleDegnen and Rosenthal (1990) argue that that "nonverbal behavior would be a key element in the mediation and emergence of feelings of rapport between participants" (1990: 288). In what they refer to as 'chemistry' (1990: 286) “....individuals experience rapport as the result of a combination of qualities that emerge from each individual during interaction". Despite this, very little research has been conducted to understand how these core competencies can affect leader-follower rapport (chemistry) in project settings.

The focus of our study is on the project manager as the 'leader' in construction projects. Smith (1999) also Muller and Turner (2010a) maintain that the increased rate of projects not achieving their objectives is a direct result of poor leadership, rather than poor project management. They calls for project managers to move beyond managing and reporting progress of a project, to adding more value through providing leadership. Goleman et al. (2002) have shown a clear correlation between the emotional intelligence and leadership style of managers and the performance of their organisations. They identified the six leadership styles of visionary, democratic, coaching pacesetting, affiliative and commanding.as being closely related to EI, with the first four fostering resonance and good performance in teams, while the last two foster dissonance. However, Turner and Muller (2005), in their review of the literature on project success factors, underlined the limited attention given to the project manager's leadership capabilities. They highlighted this apparent discrepancy between the project management literature and the general management literature, which acknowledges the role of effective leadership as a success factor that can lead to better performance in organisations.

Nevertheless, a number of studies have underlined project managers' emotional intelligence as key to project management success (El-Sabaa, 2001; Dulewicz and Higgs, 2005; Muller and Turner, 2010ab). Recently, Muller and Turner (2010b) in their study of the leadership competency profiles of project managers in successful projects found a medium to high frequency of emotional abilities, particularly 
influence, motivation and conscientiousness, within project managers in "all types of projects", including engineering projects. In addition, several studies have underlined the relationship between a project manager's emotional intelligence and their performance in construction projects (Ammeter and Dukerich, 2002; Clark, 2010; Lindebaum and Jordan, 2012; Muller and Turner, 2010b).

While the above studies signify the growing recognition of the importance of human, social and emotional factors in the management of construction projects, EI is still a new field of research, and much remains to be analysed with respect to the validity of EI construct (Mayer et al., 2008). Although social psychology studies of human and cultural factors have significantly contributed to the project management literature, reflected in the increasing empirical research and validation of conceptual models such as project 'affinity' (Dainty et al., 2005) and project 'chemistry' (Nicolini, 2002), there is a strong need for more detailed research focusing on the impact of micro level social processes on the success of construction projects (Nicolini, 2002). From the general management arena, Boyatizis (2009) argues that there is an urgent need for research into the competencies needed for effective management and leadership in order to stimulate future scholarship and application.

The purpose of the present study is to attend to this gap in knowledge. It extends the work of Nicolini (2003) on 'project chemistry' by introducing the concept of 'leaderfollower chemistry' as a means of probing the understanding of the effects a project manager's emotional abilities, particularly sensitivity and expressiveness, on the quality of interaction between a project manager and other member of the project team (leader-follower chemistry). To this point, an exploratory study was designed to answer the following research question: What is the association between a project manager's competence in two core emotional abilities- sensitivity and expressiveness - and their team member's perception of rapport (chemistry)?

In order to answer our research question, the framework adopted in this study employs a single relationship characteristic type- 'leader-follower chemistry', which is used to describe a quality of interpersonal communication at a dyadic level. Interpersonal communication is central to social interaction (Hartley, 1993) and dyadic communication occurs when two people are conversing directly with one another 
(Almore, 1979) and entails both the exchange of messages and the joint creation of meaning (Hartley, 1993). Although people in construction projects communicate 'one to one', 'one to many' and 'many to many', rapport is described in our study as a sense of chemistry in a dyadic communication framework (Tickle-Degnen and Rosenthal, 1990). Indeed, Hall et al. (2009) argue that rapport is a social construct that is intrinsically dyadic. This study's focus on exploring rapport at the level of a dyad may address the minimal attention given to individual-level constructs in project management research (Phua, 2013).

The construction project is perceived through actors or entities and relations between them. Each entity has a belonging role, which is organisation and context-specific. The roles are:

- A project manager or leader is responsible for leading the decision making process in project meetings and issue resolution among participants.

- The term followers is used to describe other specialist actors that are participating in project team meetings.

It should be noted that the terms 'leader' and 'follower' are not used in this study to denote a hierarchical distribution of power. This is mainly brought by our belief that the rapidly changing team structures and simultaneous tasks characterising construction projects, intertwined with ever increasing time and cost pressures, have resulted in projects setting their idiosyncratic frameworks for leadership (Mäkilouko, 2004). Indeed, Mäkilouko (2004) argues that project leaders often shift between taskand relationship- oriented leadership styles in order to create a productive atmosphere during the different stages of project development. Examining leadership in the project life cycle, Kloppenborg and Petrick (1999) also emphasise the important role project leaders should play in building teams with collectively ingrained virtues, particularly the responsible use and sharing of power.

Building on the existing literature on leadership, communication management, the psychological and social aspects of project management, as well as a series of surveys and live observations of site-based projects meetings, this paper provides insight into 
certain micro level social aspects of management of projects. Although a notion of 'project chemistry' is a recurring theme in project management, this study is one of the first to examine EI related inter-project social processes between professionals on construction projects. It is relevant to note that the main objectives behind this work are not to provide definitive answers or to propose a new psychology of leadership as much as (i) to deepen understanding in the construction project management community about the impact of nonverbal aspects of communication on projects; (ii) to examine the relationship between project managers' emotional abilities and the quality of leader and follower relationship in a project setting, and (iii) to develop the concept of 'leader-follower chemistry' in the management community and to set up the provisional framework for future studies.

The remainder of this paper is organized as follows: first, we discuss the concept of EI and examine the role of specific emotional ability approaches in the management literature. We then introduce the study's three main hypotheses proposing a relationship between a leader's emotional sensitivity and emotional expressiveness, and leader-follower chemistry. In the following sections, we describe the methodology and report results from analytical surveys and live observations of 68 construction professionals in Serbia. In the final section of the paper we summarise the findings, outline the managerial implications, discuss the limitations of the study and provide directions for future research.

\section{CONCEPTUAL DEVELOPMENT}

\subsection{Rapport: leader-follower chemistry}

Interpersonal relationships are an important aspect in most service industries (Gremier and Gwinner, 2000), including the construction sector (Pryke and Smyth, 2006). One specific aspect of interpersonal relationships is their 'rapport'. The concept of rapport has been investigated by a number of scholars in dyadic contexts as diverse as teacherstudent, psychologist-client, interviewer-job applicant and sales person-customer (Bernieri, 1988; Delcourt et al., 2013; Dougherty et al., 994; Gremier and Gwinner, 
2000; Tickle-Degnen and Rosenthal, 1990). Rapport has been defined by Gremier and Gwinner (2000) as a mixture of "enjoyable interactions" and "personal connection" between two individuals. Bernieri (1988, p. 121) described it as interactions that are "harmonious, smooth, "in tune with" and "on the same wave length". To TickleDegnen and Rosenthal (1990, p. 286), individuals may experience rapport when "they feel a good interaction due to "chemistry'" while Dougherty et al. (1994) frame it as a 'positive first impression'.

While the above definitions illustrate the diversity of the 'rapport' construct, they converge in describing rapport as the 'quality' of interpersonal relationships between two individuals. The outcomes of rapport may include improved communication (Crook and Booth, 1997), increased satisfaction (Ketrow, 1991), greater receptivity (Weitz, 1981) and, in the case of services, increased likelihood of purchase and customer loyalty (Brooks, 1989).

Unfortunately, the construction management literature lacks a precise definition of the rapport construct. While the value of rapport has been recognised (e.g. Iyer and Jha, 2005; Love et al., 2011; Whitfield, 2012), no operationalisation of the rapport construct exist in this body of research. In a study by Iyer and Jha (2005), good rapport between the project manager and top management was identified as one of the most important factors affecting cost performance in Indian construction projects. Love et al. (2011) also emphasised the need for rapport to support joint learning and knowledge sharing among project team members. In the work of Whitfield (2012) rapport was seen as key in avoiding or reducing conflict in construction projects.

In the next section we introduce the EI construct and review the literature related to the specific emotional ability approaches to EI.

\subsection{Emotional Intelligence (EI)}

Early research on nonverbal communication paved the way for the modern construct of Emotional Intelligence (EI) (Friedman, 1979; Rosenthal et al., 1979). A concept presented by Salovey and Mayer (1990) and later popularised by Goleman (1995, 
1998), EI is a multidimensional construct that, unlike intellectual ability (IQ), can be learned at any age (Goleman, 2000).

Three theoretical approaches guided research on EI in the scientific literature (Mayer et al., 2008). The first approach is represented by authors such as Friedman and Rosenthal and is referred to as specific-ability approaches (Friedman, 1979; Rosenthal et al., 1979). The specific-ability approach focuses on the particular set of skills that are important to emotional intelligence (Mayer et al., 2008). The second approach refers to integrative-models where several abilities are combined in order to obtain an overall assessment of EI (Mayer and Salovey, 1997; Salovey and Mayer, 1990; Mayer et al., 1990). The third category of theories is represented by the work of Goleman and his colleagues and is referred to as 'mixed models'. The mixed models of EI include emotional abilities as well as elements of personality (Goleman, 1998; Goleman et al., 2002).

This study adopts the specific-ability approach to the study of EI. Indeed, several studies have adopted the approach and have indicated that specific emotional-ability may relate to the concept of leadership (Lewis, 2000; Henderson, 2004; Rubin et al., 2005; Byron, 2007; Riggio and Lee, 2007; Mayer et al., 2008; Riggio and Reichard, 2008; Elfenbein and Eisenkraft, 2010; Rajah et al., 2011; Troth et al., 2012; Mast et al., 2012). This is in contrast to the limited evidence of the ability of integrative and mixed models approaches to predict leadership effectiveness (Barrett et al., 2001; Antonakis, 2003; Antonakis, 2004; Van Rooy and Viswesvaran, 2004). In fact, researchers on EI have recommended "examining each of the abilities separately to determine their unique contributions to leadership effectiveness" (Antonakis et al., 2009: 253).

\subsection{Specific emotional-ability approaches to EI}

Drawing on research from nonverbal communication and social psychology, Riggio and colleagues (Riggio, 1986; Riggio and Carney, 2003; Riggio and Reichard, 2008) developed a model of emotional and social skills. This framework underlines two core emotional skills: (i) skill in sensitivity, often referred to as 'perception skill' and (ii) 
skill in expressiveness, referred to as display skill. Each of these two skills operates in both the nonverbal area (emotional skills) and verbal area (social skills), and can be applied to the domain of leadership separately. Considering that the abilities in emotional sensitivity and emotional expressiveness are regarded as fundamental to EI (Davies et al., 1998; Salovey and Mayer, 1990; Mayer and Salovey, 1997; Salovey et al., 2002; Lopes et al., 2005; Tett et al., 2005; Riggio, 2006; Riggio and Reichard, 2008, Elfenbein and Eisenkraft, 2010), it would be of a significant value to understand how these skills contribute, as specific-ability approaches, to leadership (Mayer et al., 2008; Antonakis et al., 2009; Ashkanasy and Humphrey, 2011).

\subsubsection{Emotional sensitivity}

The study of emotional sensitivity grew out from an extensive body of research in nonverbal perception, particularly because emotions tend to be communicated nonverbally rather than verbally (e.g. Ekman et al., 1980). Emotional sensitivity is defined as the ability to sense the nonverbal messages of others as well as to interpret those messages accurately (Riggio, 2006). In recent years there has been some preliminary research on the importance of emotional sensitivity in the genre of leadership theories such as leader-member exchange (LMX) (Chan et al., 2007), transformational leadership (Bass and Riggio, 2006), and charismatic leadership (Conger and Kanungo, 1988).

A prerequisite for studies on the role of leaders' sensitivity abilities at the workplace were those in medical or psychological fields. For example, DiMatteo et al. (1979) found that patients awarded higher communication ratings to physicians with better sensitivity skill. Likewise, in a study by Campbell et al. (1971) clinicians who more accurately perceived emotions in others received higher effectiveness ratings from their patients. Recently, Byron (2007) drawing her sample from two diverse groups (44 part-time MBA students and 78 managers working in the hospitality industry) found that female managers, but not male, who more accurately perceived emotions received higher satisfaction ratings from their followers. The result of this study is consistent with past research findings that also showed a female superiority in perceiving nonverbal emotional expressiveness (e.g. Rosip and Hall, 2004). 
When applied to the project management context, emotional sensitivity may play an important part in achieving improved project performance. For instance, Dulewicz and Higgs (2005) conducted an extensive literature review of leadership research and subsequently underlined the importance of emotional sensitivity in the organizational change of projects. They identified 15 leadership dimensions, which they then clustered under three competences of intellectual (IQ), emotional (EQ) and managerial (MQ). A year later, Dvir et al. (2006) emphasised the general importance of emotional competency in projects. In addition, PM researchers Ralf Muller and Rodney Turner, extending the work of Dulewicz and Higgs (2005) to other industries, including the construction sector, showed the overreaching importance of project managers' emotional sensitivity in achieving project success where project managers of successful engineering projects were found to score medium to high in emotional sensitivity (Muller and Turner, 2010b).

Considering the aforementioned, if one takes a view that construction projects are settings that require, to some degree, interpersonal relations (Nicolini, 2002) then "emotional sensitivity is critical to the development of a strong relationship between a leader and individual followers" (Riggio and Reichard, 2008: 174). Such a focus may provide a notion of leader-follower chemistry, since a project manager who accurately detects follower's emotions may facilitate coordination and interpersonal functioning that may, in turn, enhance the quality of relationship (Schyns and Mohr, 2004; Riggio and Reichard, 2008). Based on the above studies and theoretical arguments, the following hypothesis is made:

Hypothesis 1: Emotional sensitivity of leaders is positively associated with leaderfollower chemistry.

\subsubsection{Emotional expressiveness}

One of the central concerns in the literature on nonverbal leadership is the type of nonverbal behaviours that are more likely to be of relevance to interpersonal relations (Bernieri, 1988; Bernieri and Gilis, 1995; Bernieri et al., 1996; Schyns and Mohr, 
2004; Dael et al., 2011). Indeed, the management and leadership research community has turned its focus to the socio-psychological field (Riggio and Reichard, 2008) since Mintzberg's (1973) classic work on managerial skills with its emphasis on interpersonal skills, such as the ability to establish and maintain social networks or the ability to deal with subordinates.

Research in social psychology has showed that the quality of relationship is transmitted nonverbally (Schyns and Mohr, 2004; Constanzo, 1992). Back in the 1960s, an American social psychologist, Albert Mehrabian found that in cases of inconsistency between verbal and nonverbal behaviour people tend to trust in the nonverbal cues (Borg, 2010). His analysis showed that overall impression made by a person was shaped by the following formula: overall impression $=7 \%$ (verbal cues) + $38 \%$ (the vocal tone) $+55 \%$ (facial or visual cues). Important to note here is not the $07 / 38 / 55$ split, but the overreaching emphasis on the importance of nonverbal communication and body language in social interaction.

The work in the field of social psychology is important to us in studying the association between emotional sensitivity and leader-follower chemistry in construction projects. Extending the work by Tickle-Degnen and Rosenthal (1987) on a theoretical construct of rapport based exclusively on expressive behaviour, Bernieri et al. (1994) designed an eighteen-scale rapport formulation that could be inferred accurately from observable behaviour. The rapport was later used in a number of studies. For instance, researchers Bernieri and Gilis (1995) used this rapport in order to examine interpersonal perception of Greek and American students. The results showed some cross-cultural similarities, considering the rapport of both samples, was deemed high in interactions characterized by; smiling, use of back-channel response (e.g. head nods), and extreme expressiveness (Bernieri and Gilis, 1995).

In another study by Bernieri et al. (1996), it was concluded that judgments of the rapport may be driven primarily by one aspect of behaviour- expressiveness. "The overall expressive level of people's interpersonal behaviour seems to be at the heart of how they will be perceived" (Bernieri et al., 1996: 124). This is in line with the findings of Tickle-Degnen and Rosenthal (1987) meta-analysis which showed a positive association between the targets' expressiveness (directed gaze, smiling, head 
nodding, forward trunk lean, direct body orientation, and posture mirroring) and evaluators' impression.

In the management literature, several studies have argued the influence of a manager's emotional display on their followers. More recently, a study by Ilies et al. (2013) involving 198 mid-level managers have shown that leader emotional expressiveness was positively correlated with followers' perceptions of leadership effectiveness. Bono and Ilies (2006) also showed that leaders' positive emotional display positively affects the followers' satisfaction. Similarly, in the context of project management, a study by Henderson (2004) supported the link between a project manager's communication competencies of encoding (active transformation of one's thoughts, ideas and feelings, into sent messages) and decoding (active listening) and team member satisfaction. The findings indicate that project managers can influence their followers through nonverbal communication channels. Henderson (2004) found that project managers' encoding and decoding behaviour relates to a $46 \%$ variance in project team satisfaction.

To conclude, the above arguments may suggest that project leaders who use their ability to express emotions to inspire and motivate via the emotional contagion process (i.e. the transfer of moods among people in a group, Barsade, 2002) may, in turn, build strong emotional ties with their followers (Bernieri and Gilis, 1985; Bernieri et al., 1986; Bernieri, 1988; Bono and Ilies, 2006; Groves, 2006; Riggio and Reichard, 2008; Dael et al., 2012; Ilies et al., 2013). The following hypothesis is presented, based upon these concepts:

Hypothesis 2: Emotional expressiveness of leaders is positively associated with leader-follower chemistry.

\subsubsection{The relationship between emotional sensitivity and emotional expressiveness}

For decades social psychologists have been intrigued by a display-perception link (Elfenbein and Eisenkraft, 2010). As noted earlier, emotional or nonverbal 
communication is a process that involves both sending coherent messages to others and accurately interpreting messages that others send (Borg, 2010).

In the field of social psychology, there has been a debate about the relationship between display and perception. The work of Eisenberg et al. (1998) assumes that display and perception skills develop in tandem. They argue that parents who are better perceivers may send better feedback to encourage children's expressive skills. On the other hand, studies such as that of Halberstadt (1986) assert that in low expressive environments individuals may become more sensitive in order to relate effectively with their family members. By contrast, in a high expressive environment, individuals do not need to develop high perception skills.

The above diversity in arguments on theoretical perspectives of a display-perception link may lead to a distinction between displays that are exhibited or 'posed' purposely versus those occurring spontaneously. That is, people not expressive in spontaneous situations, may still be proficient at posing when asked explicitly to do so. Recently, Elfenbein and Eisenkraft (2010) in their meta-analysis review supported this argument by showing that the nonverbal display-perception relation was greater for studies with intentional communication displays than those having spontaneous, naturalistic or combination of display types. The third hypothesis linking to the themes above, is:

Hypothesis 3: The emotional sensitivity of leaders is positively associated with their emotional expressiveness.

Drawing on a series of theoretical arguments and empirical evidence, this section has outlined the theoretical approach adopted in examining how a project leader's emotional abilities- sensitivity and expressiveness- may influence the quality of interaction with their followers in a construction project setting. In the next section, the data collection methodology is outlined and the relevant measurement instruments are discussed. 


\section{METHODS}

\subsection{Context}

The present study was conducted in the Republic of Serbia. Recently, alliancing has increased in importance as a procurement route in Serbia for infrastructure and construction projects. The Serbian government is increasingly procuring major construction projects through some form of alliancing model. For instance, the Belgrade Metro, with an estimated cost of more than 1 billion $€$, is just one of the major infrastructure projects that is to be delivered in this way. This new approach changes traditional business environments and requires a different set of relationships between project participants (Walker and Walker, 2011). In such a new construction environment, a diverse set of construction professionals from a broad range of sectors and backgrounds work closely together in a cooperative and collaborative manner throughout the front-end and back-end of a project (Morris, 2013). In addition, Furnham and Petrova (2010) adopting Hofstede and Hofstede's (2005) five cultural dimension approach classified Serbia as a 'low individualism' nation country, high in collectivism; and as a 'high power distance culture'; one which cultivates vertical hierarchies, autocratic leadership style, strict supervision and poor focus on followers. The system in place in such countries, a majority of which are ex-communist states, can be regarded as closed systems (Scot, 1992), hence there is a need for particular emphasis on contemporary soft management approaches. Indeed, as a consequence of the new construction environment, project managers' emotional competence may be a key to project management success (Dulewicz and Higgs, 2005; El-Sabaa, 2001; Muller and Turner, 2010b).

\subsection{Research design, participants and procedures}

This study adopted a quantitative approach as the aim was to study the relationship between the variables in order to test the hypotheses. The quantitative method is defined as "an inquiry into a social or human problem based on testing a hypothesis or 
a theory composed of variables and analysed with statistical procedures, in order to determine whether the hypothesis or the theory hold true" (Creswell, 1994 cited in Naoum, 2007: 37-38).

A managing director of a medium-sized Serbian AEC (Architecture, Engineering and Construction) company, was approached. After the background of the research was presented and data collection technique explained, the managing director gave permission for the research to be carried out on a number of projects currently undertaken by the company. Furthermore, the managing director shared valuable contacts within other companies willing to participate in the research, all located in dispersed geographical regions across Serbia.

In addition, the researcher's non-participant observation of project meetings was considered the most suitable approach for data collection. Non-participant observation is a systematic data collection approach in which researchers utilise all of their senses to examine people in naturally occurring situations with limited interaction with the people observed (Patton, 2005). The collection of observational data was most appropriate for our study because of the importance of studying the phenomenon in its natural setting and where self-reported data (asking people what they do) is expected to differ from actual behaviour (what people actually do) (McDonald, 2008). This is particularly important, given the limitations of the self-report measures such as: peoples' tendency to report having higher abilities than they actually believe they have, with narcissism explaining $20 \%$ of the variance in self-reported abilities; in addition people are often found to be unrealistic in judging themselves, as they actually cannot compare their abilities with the ones of their colleagues (Cote and Miners, 2006). In addition, the observations entailed 'live' meetings as opposed to other options (e.g. virtual meetings). This is because people communicate largely through body language and tone of voice. These elements are present in face-to-face communication, and allowed us to derive a wealth of accurate information and meaning from tone of voice and facial expressions, even when they contradicted what was being said (such as when a person is lying or speaking in an incoherent way). On the other hand, it is only the tone of voice that is often conveyed through communication in virtual meetings, and this lack of body and facial expressions is seen to result in increased anxiety, confusion, and miscommunication (Tugrul et al., 2012). 
We followed the methodology provided in Tickle-Degnen and Rosenthal (1990) in which they argue that rapport is a development phenomenon built throughout an interaction and relationship. They also stated that rapport is usually measured between new acquaintances because later, with increased familiarity between participants, interactions tend to be more loosely structured and participants develop their own conventions and show more diversity in the ways they communicate thoughts to one another. Following the advice of Tickle-Degnen and Rosenthal (1990) rapport in this research was measured between unacquainted individuals (Bernieri and Gillis, 1995). This criterion mean that two important research design decisions were taken: (a) We aimed to observe 'first' site based meetings involving the project manager and other members of the project team. This, in turn, limited our sample to construction projects at the beginning of their construction stages (CIOB, 2010). Following this criterion, twelve diverse projects were selected to be included in the study (refer to Table 1 for project details), with a contract value from $\$ 1$ million to value of $\$ 5$ million. One project (US embassy) had a value of around $\$ 117$ million. (b) Those meeting participants who were familiar with the target project managers were excluded from the study. In total 68 individuals (12 project managers and 56 team members) participated in the study (see Table 1 for the distribution of professional groups among different projects).

\section{<INSERT TABLE 1 ABOUT HERE $>$}

It should be noted that rapport in this study is examined from only one side of the dyad as we focused solely on the project team member's perception of rapport in their interaction with the project manager. However, we acknowledge that rapport develops only in interaction between individuals (Tickle-Degnen and Rosenthal 1990). In fact, Bernieri et al. (1996) maintains that the concept of rapport is distinct because it "does not reside within a single individual" (p. 114). We recognise this limitation in looking at only one side of a dyadic construct and strongly recommend that rapport is examined from both perspectives of the dyad in future studies. This will enable a more accurate assessment of the amount of rapport in a relationships as well as enable a comparison of each party's perception of the most effective rapport building behaviour (Gremler and Gwinner, 2000). 
Before each project meeting, the nature of the study was briefly explained to all participants. This included an introduction to the tests that were used by the two researchers during the meeting (body movement and facial check lists) and those that needed to be completed by participants after the meeting (Test of Non-Verbal Cue Knowledge- 'TONCK' by project managers and 'Rapport' test by team members-both explained in more detail below). Respondents were assured that all responses would remain anonymous and no identifying information would be used. Some meeting participants refused to take part in the research. A response rate of $74.67 \%$ was achieved, which is considered adequately representative of the target population from which its members are selected (Patel et al., 2003) (See Table 2 for details of the response rate). It should also be noted that on two projects (US embassy and the Electrical Utility Company of Serbia) it was not possible to attend and observe the meetings due to the contractual obligations, thus, reducing the size of our sample to ten observations. This may have weakened the testing of hypothesis 2 and 3 (refer to section 4.2 and 4.3 for more details). In total, the TONCK was completed by 12 project managers and the Rapport test by 56 team members. As argued by Wilson and Morgan (2007), for the type of analysis performed in our paper, a sample size of 50 or more is regarded as reasonable giving sufficient power to make correlation-based conclusions.

\section{<INSERT TABLE 2 ABOUT HERE $>$}

In addition, all project participants were able to receive the research findings at the end of the study. Concurring with the benefits argued by Alreck and Settle (2004), this helped to strengthen existing and build new relationships with the participants, whereas the participants were able to capture some useful lessons learned, particularly in relation to the study's findings.

\subsection{Assessment instruments}

Three assessment instruments were used in this study: emotional sensitivity test, emotional expressiveness test, and follower's rapport questionnaire. They are briefly described in the forthcoming part of the paper. 


\subsubsection{Emotional sensitivity test}

The targeted project managers' emotional sensitivity was assessed using the Test of Nonverbal Cue Knowledge (TONCK) (Rosip and Hall, 2004). In support of convergent validity, the TONCK was found to be significantly correlated with other similar tests of emotional sensitivity, for example the adult faces and voices tests of the Diagnostic Analysis of Nonverbal Accuracy (DANVA) and the video and audio tests of the Profile of Nonverbal Sensitivity (PONS). Since its development, the TONCK has been increasingly used in a number of studies with populations diverse in terms of gender, profession, race and intelligence (e.g. Ingersoll, 2010). The TONCK depicts a pool of 81 true/false items (see Table 3). Items such as 'someone's smile can affect your mood, were drawn out from a diverse set of materials on nonverbal communication. The sum of correct answers represents the percentage in a manner whereby the higher scores indicate higher knowledge of emotional sensitivity (Rosip and Hall, 2004).

\section{<INSERT TABLE 3 ABOUT HERE $>$}

\subsubsection{Emotional expressiveness test}

Following the advice of Bernieri and Gillis (1995), the behavioural cues of targeted project managers in this research were coded at individual level of analysis in terms of their frequency. Coding data was generated for a majority of cues using two checklists'body movement' checklist and 'facial movement' checklist (see Tables 4 and 5 respectively). The former was adopted from Bull (1983) and used to record the managers' specific body (head, trunk, arm, leg) movements. The latter, adopted from Ekman and Freisen (1978), was used to record facial expression movements depicting 32 facial features. The coding was performed during the site-based project meetings by the principal researcher who used the body movement checklist to record the frequency of the project manager's body (head, trunk, arm, leg) movements as well as taking field notes. A research assistant was responsible for observing any facial movement made by the project manager and recording these on the facial movement 
checklist. We recognise that a weakness in this live observation by the two researchers is that the subjects, that is the project managers, knowing they are being watched, may modify their behaviour and display their 'ideal self' rather than their true self. This phenomenon, also referred to as the 'observer effect' or the 'Hawthorne effect' is well known in observational inquiry and is considered an unavoidable bias that is difficult to eliminate and should be taken into account when interpreting the findings (e.g. Holigrocki et al., 1999; Parsons, 1974).

\section{<INSERT TABLE 4 ABOUT HERE $>$ $<$ INSERT TABLE 5 ABOUT HERE $>$}

It is important to note that video recording was not permissible due to the commercial sensitivity of some of the issues discussed in those project meetings. As Heath et al. (2010) proposed, the use of a video recording device would have been ideal in such a setting as it would have offered a detailed recording of the communication and provided the researcher with access to the style of speech (for example volume, pitch and tone of voice) as well as body behaviour (such as eye gaze and facial expression). Also, it would have enabled the capture of what occurred in the setting by transcribing and 're-opening' the recordings during the analysis process (Heath et al., 2010). Due to the restrictions placed on the observation, however, data was mainly gathered by ticking the appropriate boxes on the checklists. The use of recording is highly recommended for future research, were feasible, as it can significantly improve the quality of the data gathered (Jones and LeBaron, 2002).

\subsubsection{Rapport test}

The chemistry between the targeted project managers and their followers was measured using a simple 0-8 scale of the 18-item questionnaire (Table 6) adopted from Bernieri et al. (1994). The questionnaire depicts interaction characteristics such as well-coordinated, boring, and cooperative, among others. This rapport test was used in a number of studies with diverse contexts and participants (e.g. Grahe and Bernieri, 1999). In support of its construct validity, responses on the rapport scale are in relationship with the frequency of behaviour coordination observed in only a thin slice 
of the total behavioural stream (Bernieri, 2004). This indicates that scores on rapport can be used to predict social and psychological outcomes at levels significantly above those expected by chance (Ambady and Rosenthal, 1992).

<INSERT TABLE 6 ABOUT HERE $>$

\section{RESULTS}

SYSTAT 12 statistical framework was utilized for performing all statistical analyses. The pre-processing activities were done in MS Excel 2010.

\subsection{Hypothesis 1 results}

The aim of the first study was to examine the relationship between emotional sensitivity and the quality of leader-follower chemistry. The data gathered from 56 participants were organized in a form of matrix with 56 rows and 20 columns, where the first 18 columns (denoted by $\mathrm{X}_{1}, \mathrm{X}_{2}, \ldots \mathrm{X}_{18}$ ) presents the answers to the rapport rating questionnaire on the integer scale from 0 to 8 , column 19 (denoted by $\mathrm{X}_{\text {tot }}$ ) represents an aggregate value of all answers in one row, and the last column (denoted by $\mathrm{Y}$ ) presents the score on test of emotional sensitivity (TONCK) of a manager on the integer scale from 0 to 81 . $\mathrm{X}_{\text {tot }}$ is calculated as a sum of the positively correlated items plus the sum of expressions of form $\left(8-\mathrm{X}_{\mathrm{i}}\right)$ where $\mathrm{X}_{\mathrm{i}}$ is negatively correlated item. For example if a participant has rated the interaction as 'boring' with a score of 6 , then the formula will be $8-6$. This data set (consisting of 56 rows) will be denoted as $\mathrm{D}_{1}$ below. The rapport questionnaire was completed anonymously which, it is argued, improves the representativeness of the data sample. Apart from these data, we use the average scores inside projects only as insight in project similarities (differences), data set $\mathrm{D}_{2}$. Basic descriptive statistics for $\mathrm{D}_{2}$ is given in Table 7 .

<INSERT TABLE 7 ABOUT HERE $>$ 
The first issue of interest was to show the internal consistency (reliability) of the collected data sets. Cronbach alpha coefficient (DeVellis, 1991) was calculated for $\mathrm{D}_{1}$ $(\alpha=0.68)$ in order to support this property. The obtained alpha suggests good internal consistency. TONCK scores (variable $Y$ ) for $\mathrm{D}_{1}$ had mean accuracy of $68 \%$ (55.30 out of $81, \min =34, \max =65, \mathrm{SD}=7.84$ ), with gender differences (females $\mathrm{M}=60.33$, $\mathrm{SD}=5.03$ scoring higher than males $\mathrm{M}=52, \mathrm{SD}=8.75$ ). It is also shown that these scores were significantly higher than chance $(50 \%)$ by employing t-test for mean: $t$ (56)=13.103, $\mathrm{p}$-value $<0.001$ for $\mathrm{D}_{1}$.

We performed 2-tailed Pearson product moment correlation test to test Hypothesis 1, that is whether the targeted project managers who have higher knowledge of emotional sensitivity (TONCK) receive from their team colleague higher interaction ratings for positively posed questions on the rapport scale or lower interaction ratings for negatively posed questions on the rapport scale.

We tested association between variable $\mathrm{X}_{\text {tot }}$ and values on TONCK and results showed correlation of 0.722 and p-values $<0.01$ (see Table 8 ). Therefore, the null hypothesis, that there is no significant relationship between the manager's knowledge of emotional sensitivity and follower's ratings on the quality of leader and follower chemistry, can be rejected, meaning that there is significant relationship between nonverbal cue knowledge and scores on rapport.

<INSERT TABLE 8 ABOUT HERE $>$

\subsection{Hypothesis 2 results}

The aim of Study 2 was to investigate an association between emotional expressiveness and the quality of leader and follower relationship. The statistical approach described in Study 1 was used. However, as noted before, instead of having a sample of 12 projects, only 10 projects were included in the analysis, because 2 projects (US embassy and the Electrical Utility Company of Serbia) had restrictions relating to the live observation of site-based project meetings. Accordingly, the data 
gathered from 49 participants were organized in a form of matrix with 49 rows and 24 columns, where the first 18 columns (denoted by $\mathrm{X}_{1}, \mathrm{X}_{2}, \ldots \mathrm{X}_{18}$ ) present the answers to the rapport rating questionnaire on the integer scale from 0 to 8 , column 19 (denoted by $\mathrm{X}_{\text {tot}}$ ) represents a sum of all answers in one row, and the last five columns (denoted by $\mathrm{Y}_{1}, \mathrm{Y}_{2}, \mathrm{Y}_{3}, \mathrm{Y}_{4}$ and $\mathrm{Y}_{5}$ ) present the frequency of the targeted project manager's body-facial movements. In further text, the first data set (consisted of 49 rows) will be denoted as $\mathrm{D}_{3}$. Additionally, similar to Study 1 we used the average scores inside projects, only to show project similarities (differences). This is presented by basic descriptive statistics in data set $\mathrm{D}_{4}$, given in Table 9.

\section{$<$ INSERT TABLE 9 ABOUT HERE $>$}

Cronbach alpha coefficient was calculated in order to show the internal consistency (reliability) of the collected data set. The obtained alpha for $\mathrm{D}_{3}(\alpha=0.80)$ suggests good internal consistency.

In the second hypothesis, we used the 2-tailed Pearson product moment correlation test between variables $\mathrm{Y}_{1}, \mathrm{Y}_{2}, \mathrm{Y}_{3}, \mathrm{Y}_{4}$ and $\mathrm{Y}_{5}$ on one side and variable $\mathrm{X}_{\text {tot }}$ on the other side. The results showed statistically significant correlations in all cases: 0.528 ( $\mathrm{Y}_{1}$, $\left.\mathrm{X}_{\text {tot }}\right), 0.460$ ( $\left.\mathrm{Y}_{2}, \mathrm{X}_{\text {tot }}\right), 0.401\left(\mathrm{Y}_{3}, \mathrm{X}_{\text {tot }}\right), 0.364$ (Y $\left.4, \mathrm{X}_{\text {tot }}\right)$ and 0.409 ( $\left.\mathrm{Y}_{5}, \mathrm{X}_{\text {tot }}\right)$ with all pvalues $<0.01$ (see table 10$)$.

This analysis was performed to test Hypothesis 2, which is whether the targeted project managers who use higher frequency of emotional expressiveness receive from their followers higher interaction ratings for positively posed questions on the rapport scale or lower interaction ratings for negatively posed questions on the rapport scale. It is shown that in all cases, $\mathrm{Y}_{1}, \mathrm{Y}_{2}, \mathrm{Y}_{3}, \mathrm{Y}_{4}$ and $\mathrm{Y}_{5}$, the null hypothesis can be rejected with $\mathrm{p}$-values $<0.01$, meaning that there is significant relationship between frequency of emotional expressiveness and scores on rapport.

$<$ INSERT TABLE 10 ABOUT HERE $>$ 


\subsection{Hypothesis 3 results}

Study 3 aimed to test Hypothesis 3, that the emotional sensitivity and emotional expressiveness abilities of project managers are positively related to each other given the participants' expectations of the study. The results from Table 11 indicate the modest correlation between the scores on the TONCK (Y) and body (Y1-head, Y2trunk, $\mathrm{Y}_{3}$-arm, and $\mathrm{Y}_{4}-\mathrm{leg}$ ) and facial $\left(\mathrm{Y}_{5}\right)$ movements. Hence the null hypothesis, that there is no correlation between emotional sensitivity and emotional expressiveness of managers given the participants' expectations of the study, can be rejected. Study 3 found a positive relationship between emotional sensitivity and emotional expressiveness given the intentional environment.

<INSERT TABLE 11 ABOUT HERE $>$

\subsection{A provisional leader-follower chemistry model}

Based on the first two studies we developed the leader-follower chemistry model (see Figure 1). Its research objective was to explore 'chemistry' a quality of interaction between leaders and their follower. In order to address this issue, regression analyses between project manager's emotional sensitivity and expressiveness, and the quality of 'leader-follower chemistry' were performed.

\section{$<$ INSERT FIGURE 1 ABOUT HERE $>$}

In order to make prediction model of Y (emotional sensitivity) based on $\mathrm{X}_{\text {tot }}$ (rapport), we performed the linear regression using "ENTER" method in SPSS. The results showed the following regression formula: $\mathrm{X}_{\mathrm{tot}}=2.174 \mathrm{x} \mathrm{Y}-28.409$ with $\mathrm{p}$-value for the linear factor $<0.01$, while the constant factor was not significant i.e. $>0.0$ (see Table 12).

$<$ INSERT TABLE 12 ABOUT HERE $>$ 
Multiple regression (with stepwise heuristic method) was used to attain multiple regression where dependent variable is $\mathrm{X}_{\text {tot }}$ and independent variables are $\mathrm{Y}_{1-5}$. The analysis is performed on data sets where all individual data were used and results showed that only $\mathrm{Y}_{1}$ variable was significant. The produced model is as follows $\mathrm{X}_{\text {tot }}$ $=0.785 \times Y_{1}+70.20$. The constant factor had $p$-value $<0.001$ while $p$-value for $Y_{1}$ significance was $<0.001$ (see Table 13).

\section{$<$ INSERT TABLE 13 ABOUT HERE $>$}

\section{DISCUSSION}

Three hypotheses have been tested in this research study. The first hypothesis examined the association of project manager's emotional sensitivity with team member's perception of rapport. Results have shown a significant emotional sensitivity-rapport relationship with a project manager's emotional sensitivity positively correlated with team member's perception of rapport. These results contribute the dimension of rapport (i.e. chemistry) to studies which found a positive relation between a manager's ability to accurately perceive non-verbal emotional expressions and outcomes such as higher performance ratings from their supervisor and higher satisfaction ratings from their subordinates (Henderson, 2004) and team member productivity (Henderson, 2004). Moreover, the results provide progress to Muller and Turner's (2010ab) work, adding emotional sensitivity to the emotional dimensions of influence, motivation and conscientiousness identified in their study as soft factors for effective leadership competency. In addition, our study's focus on examining unacquainted individuals may suggest that project managers with high emotional sensitivity are best assigned to more heterogeneous and complex construction projects because of their ability to swiftly establish rapport with new contacts.

The second hypothesis tested an association of project manager's emotional expressiveness with team member's perception of rapport. The results have shown a 
significant relationship between frequency of emotional expressiveness and scores on rapport. In a project environment this means that manager's body and facial gestures, such as signals of active listening e.g. nodding (Borg, 2010) could result in positive openness to potential relationships. Although previous studies were employed in different contexts, there are similarities across the studies' findings. For instance, Bernieri and Gillis (1995), measuring the interpersonal perception of Greek and American students, found that the rapport was driven primarily by one aspect of behaviour- the use of back-channel response (e.g. head nods). While, Tickle-Degnen et al. (1987) reported positive association between target's trunk movements and evaluator's impression. On the other hand, although management researchers (e.g. Bono and Ilies, 2006) have supported a link between encoding competency of managers and team member satisfaction, they were not specific in their explanation of the word 'encoding'. Furthermore, our study's employment of performance-based tests may offer greater accuracy as opposed to previous studies that used self-rating approaches (e.g. Henderson, 2004), which proved to be unsuccessful in predicting emotional accuracy (Riggio and Reichard, 2008). Although the current study is based on a small sample of participants, it offers a quantitatively supported argument that project managers can influence a sense of collaborative relationship through their use of body and facial movements.

The final hypothesis investigated a display-perception link. It was found that the positive, but modest in level, relationship between emotional knowledge and emotional expressiveness implies that managers could use these two emotional abilities in tandem. This is in line with Elfenbein and Eisenkraft's (2010) metaanalysis, which showed that people not expressive in spontaneous situations, may still be proficient at posing when asked explicitly to do so.

In addition, based on the empirical evidence, we present the leader-follower chemistry model, which emphasizes the importance of a project manager's emotional abilities, particularly sensitivity and expressiveness, in a dyadic communication frameworkleader-follower. These findings could be important for construction enterprises that have shed much of their operational employment through subcontracting, and have focused on retaining the professional project managers. The emotionally competent 
project manager is perhaps the most important element in maintaining good 'chemistry' in such diverse project coalition.

\section{CONCLUSION}

The adoption of non-confrontational attitudes demands a deeper understanding of micro level social processes, particularly concerning the interpersonal relationships between leaders and followers. Knowledge of tools and techniques is desirable, although it must be acknowledged that the construction industry is characterised by pervasive adversarial relationships and interpersonal and interorganizational conflicts (Loosemore and Galea, 2008) resulting from aggressive competition, narrow profit margins and hostile management approaches (Smithers and Walker, 2000; Holt et al., 2000). These challenges that a project manager is faced with in today's contracting environments, especially alliances, demand a balance between management and leadership abilities in order to achieve greater performance targets as well as creating good relationships amongst actors of the project milieu (Toor et al., 2007).

The research presented here was designed to determine the effect of a project manager's EI competencies on the quality of interpersonal interaction with their followers, being other members of the project team. Descriptive and inferential statistics were used to examine the relationship between a project manager's emotional competencies, in terms of sensitivity and expressiveness, and leader-follower chemistry. Following a quantitative study involving 68 construction professionals, the findings suggest that a project manager's emotional sensitivity and expressiveness may explain variance in the quality of leader-follower chemistry. Based on the empirical evidence, a leader-follower chemistry model is introduced, which incorporates and predicts the relationship between leaders' emotional sensitivity and expressiveness and followers' perception of rapport in a leader-follower communication dyad. The model advances our understanding of leadership in project management, particularly the interaction between project leaders and other project participants, with a focus on the human skills that are often afforded limited attention in the project management bodies of knowledge (Muller and Turner, 2010ab). The 
model constitutes a valuable extension to Nicolini's (2002) notion of 'project chemistry' and sets up a provisional framework for future studies.

Following further validation and refinement, the developed leader-follower chemistry model may have several applications in practice. First, the model assists in enhancing our understanding of how emotional sensitivity and expressiveness can shape the quality of relationships between project managers and other members of the project team. Thus, seeking, appointing and promoting individuals who possess these skills would naturally increase the quality of interaction in projects, particularly in construction where management styles are often aggressive and authoritarian (Smithers and Walker, 2000). Second, a number of studies have observed the reluctance of project managers to engage with EI issues and questioned the 'trainability' of EI (Lindebaum and Cassell, 2012). It is, however, important for the actors of heterogeneous project settings to engage with EI-related issues in order to enhance their capabilities to quickly establish strong ties with a culturally, educationally and professionally diverse (heterogeneous) group of stakeholders. The correlation between project manager's emotional sensitivity and the quality of leaderfollower chemistry implies a rationale for such soft skills training. Finally, when establishing a project team, project managers may consider members' emotional competencies in order to promote a working environment that encourages an interchange of ideas through good interpersonal interaction.

Several limitations are inherent in this research study. Foremost, the generalizability of the research findings is limited given the modest sample size. Thus, validating the model should be the focus of a future study. Another limitation of this study is the lack of use of control variables mostly because of time constraints. Further research should focus on expanding the sample size and control some of the variables such as gender, which is found to be crucial in nonverbal literature. Moreover, since several researchers (e.g. Lopes et al., 2005) have found that the quality of interpersonal relations is influenced by factors such as personality or motivation, it would be interesting for future studies to investigate interactions between emotional knowledge and the 'Big Five' personality traits (Goldberg, 1990). Further studies may also consider the cultural differences that exist in nonverbal behaviour and their impact on the establishment of good and supportive relations inside the project team. Subsequent 
research studies could explore EI and how it supports or hinders leadership in the team environment. Furthermore, although the follower's perspective may be of primary importance in a project setting, there are limitations in looking at only one side of a dyadic construct. It may be of value to measure rapport from both sides of the dyad in order to access more accurately the quality of 'chemistry' between leaders and their followers. This is another area for future studies.

We consider this research as a first-step in examining the influence of EI, and particularly the joint influence of emotional sensitivity and expressiveness, on leaderfollower chemistry, with the hope of stimulating interest and paving the way for future research on this important dimension of project management.

\section{REFERENCES}

Almore, G.M. (1979) Dyadic communication, The American Journal of Nursing, Vol. 79, No. 6, 1076-78.

Alreck, P. L. and Settle, R. B. (2004) The survey research handbook, McGraw- Hill/Irwin, Boston.

Ambady, N. and Rosenthal, R. (1992) Thin slices of expressive behaviour as predictors of interpersonal consequences: a meta analysis, Psychological Bulletin, Vol. 111, No. 2, 256-274.

Ammeter, A. P. and Dukerich, J. M. (2000) Leadership, team building, and team member characteristics in high performance project teams, Engineering Management Journal, Vol. 14, No. 4, 3-10.

Antonakis, J. (2003) Why emotional intelligence does not predict leadership effectiveness, The International Journal of Organizational Analysis, Vol. 11, No. 4, 355-361.

Antonakis, J. (2004) On why emotional intelligence will not predict leadership effectiveness beyond IQ or the Big Five: an extension and rejoinder, Organizational Analysis, Vol. 12, No. 2, 171-182.

Antonakis, J., Ashkanasy, N. M. and Dasborough, M. T. (2009) Does leadership need emotional intelligence? The Leadership Quarterly, Vol. 20, No. 2, 247-261.

Ashkanasy, N. M. and Humphrey, R. H. (2011) Current emotion research in organizational behavior, Emotion Review, Vol. 3, No. 2, 214-224.

Barrett, G. V., Miguel, R. F., Tan, J. A. and Hurd, J. M. (2001) Emotional intelligence: the 
Madison Avenue approach to science and professional practice, Paper presented at the annual meeting of the Society for Industrial and Organizational Psychology, San Diego, CA.

Barsade, S. G. (2002) The ripple effect: Emotional contagion and its influence on group behavior. Administrative Science Quarterly, Vol. 47, No. 4, 644-675.

Bass, B. M. and Riggio, R. E. (2006) Transformational Leadership, Lawrence Erlbaum Associates, NJ.

Bernieri, F. J. (1988) Coordinated movement and rapport in teacher-student interactions, Journal of Nonverbal Behavior, Vol. 12, No. 2, 120-138.

Bernieri, F. J. (2004) The expression of rapport, in Manusov, V. L. (ed.) The sourcebook of nonverbal measures: Going Beyond Words, Lawrence Erlbaum Associates, NJ.

Bernieri, F. J., Davis, J., Rosenthal, R. and Knee, C. (1994) Interactional synchrony and rapport: measuring synchrony in displays devoid of sound and facial affect, Personality and Social Psychology Bulletin, Vol. 20, No. 3, 303-311.

Bernieri, F. J. and Gillis, J. S. (1995) The judgment of rapport: a cross-cultural comparison between Americans and Greeks, Journal of Nonverbal Behavior, Vol. 19, No. 2, 115130.

Bernieri, F. J., Gillis, J. S., Davis, J. M. and Grahe, J. E. (1996) Dyad rapport and the accuracy of its judgment across situations: a lens model analysis, Journal of Personality and Social Psychology, Vol. 71, No. 1, 110-129.

Bono, J. E. and Ilies, R. (2006) Charisma, positive emotions, and mood contagion, The Leadership Quarterly, Vol. 17, No. 4, 17-34.

Borg, J. (2010) Persuasion: The art of influencing people, $3^{\text {rd }}$ edition, Pearson Education.

Boyatzis, R. E. (2009) Competencies as a behavioral approach to emotional intelligence, Journal of Management Development, Vol. 28, No. 9, 749-770.

Brooks, M. (1989) Instant Rapport. Warner Books, New York.

Bull, P. E. (1983) Body movement and interpersonal communication, John Wiley \& Sons, UK.

Byron, K. (2007) Male and female managers ability to read emotions: relationships with supervisor's performance ratings and subordinates' satisfaction ratings, Journal of Occupational and Organizational Psychology, Vol. 80, No. 4, 713-733.

Campbell, R. J., Kagan, N. and Krathwohl, D. R. (1971) The development and validation of a scale to measure affective sensitivity (empathy), Journal of Counseling Psychology, Vol. 18 , No. 5, 407-412.

Chan, G., Kirkman, B. L., Kanfer, R., Allen, D. and Rosen, B. (2007) A multilevel study of leadership, empowerment, and performance in teams, Journal of Applied Psychology, Vol. 92, No. 2, 331-346.

CIOB (2010) Code of Practice for Project Management, 4th edition, Blackwell Publishing. 
Clarke, N. (2010) Emotional intelligence and its relationship to transformational leadership and key project manager competences, Project Management Journal, Vol. 28, No. 3, 110.

Clarke, N. (2010) Projects are emotional: How project managers' emotional awareness can influence decisions and behaviours in projects, International Journal of Managing Projects in Business, Vol. 3, No. 4, 604-624.

Conger, J. and Kanungo, R. (1988), Charismatic leadership: The elusive factor in organizational effectiveness. The Jossey-Bass management series. Jossey-Bass, San Francisco, CA, US.

Constanzo, M. (1992) Training students to decode verbal and nonverbal cues: effect on confidence and performance, Journal of Educational Psychology, Vol. 84, No. 3, 308313.

Cote, S. and Miners, C. T. H (2006) Emotional intelligence, cognitive intelligence, and job performance, Administrative Science Quarterly, Vol. 51, No. 1, 1-28.

Crook, C. and Booth, R. (1997), Building Rapport in Electronic Mail Using Accommodation Theory, S.A.M. Advanced Management Journal, Vol. 62, No. 1, 4-13.

Dael, N., Mortillaro, M. and Scherer, K. R. (2011) Emotion expression in body action and posture, Emotion, Advance online publication, Vol. 12, No. 5, 1085-1101.

Dael, N., Mortillaro, M. and Scherer, K. R. (2012) The body action and posture coding system (BAP): development and reliability, Journal of Nonverbal Behavior, Vol. 36, No. 2, 97 121.

Dainty, A. R., Bryman, A., Price, A. D., Greasley, K., Soetanto, R., and King, N. (2005) Project affinity: the role of emotional attachment in construction projects, Construction Management and Economics, Vol. 23, No. 3, 241-244.

Davies, M., Stankov, L., and Roberts, R. D. (1998) Emotional intelligence: in search of an elusive construct, Journal of Personality and Social Psychology, Vol. 75, No. 4, 9891015.

Delcourt, C., Gremler, D. D., van Riel, A. C., and van Birgelen, M. (2013) Effects of perceived employee emotional competence on customer satisfaction and loyalty: The mediating role of rapport, Journal of Service Management, Vol. 24, No. 1, 5-24.

DeVellis, R. F. (1991) Scale Development: theory and applications, Sage, Newbury Park.

DiMatteo, M. R., Friedman, H. S. and Taranta, A. (1979) Sensitivity to bodily nonverbal communication as a factor in practitioner-patient rapport, Journal of Nonverbal Behavior, Vol. 4, No. 1, 18-26.

Dougherty, T., Turban, D. and Callendar, J. (1994) Confirming First Impressions in the Employment Interview: Afield Study of Interviewer Behavior, Journal of Applied Psychology, Vol. 79, No. 5, 659-65. 
Dulewicz, V. and Higgs, M. J. (2005) Assessing leadership styles and organizational context, Journal of Managerial Psychology, Vol. 20, No. 2, 105-123.

Dvir, D., Sadeh, A. and Malach-Pines, A. (2006) Projects and project managers: the relationship between project manager's personality, project, project types, and project success, Project Management Journal, Vol. 37, No. 5, 36-48.

Egan, J. (1998), Rethinking Construction, Department of the Environment, Transport and the Regions, UK.

Eisenberg, N., Cumberland, A. and Spinrad, T. L. (1998) Parental socialization of emotion, Psychological Inquiry, Vol. 9, No. 4, 241-273.

Ekman, P. and Freisen, W. V. (1978) Facial Coding System: a technique for the measurement of facial movements, Consulting Psychologists Press, California.

Ekman, P., Friesen, W. V., and Ancoli, S. (1980) Facial signs of emotional experience, Journal of Personality and Social Psychology, Vol. 39, No. 6, 1125-1134.

Elfenbein, H. A. and Eisenkraft, N. (2010) The relationship between displaying and perceiving nonverbal cues of affect: a meta-analysis to solve an old mystery, Journal of Personality and Social Psychology, Vol. 98, No. 2, 301-318.

El-Sabaa, S. (2001) The skills and career path of an effective project manager, International Journal of Project Management, Vol. 19, No. 1, 1-7.

Friedman, A. (1979) Framing pictures: the role of knowledge in automatised encoding and memory for gist, Journal for Experimental Psychology: General, Vol. 108, No. 3, 316355.

Furnham, A. and Petrova, E. (2010) Body language in business: decoding the signals, Palgrave MacMillan, London.

Goldberg, L. R. (1990). An alternative" description of personality": the big-five factor structure. Journal of personality and social psychology, Vol. 59, No. 6, 1216-1229.

Goleman, D. (1995) Emotional intelligence, Bantam, New York.

Goleman, D. (1998) Working with emotional intelligence, Bantam, New York.

Golman, D. (2000) Leadership that gets results, Harvard Business Review, 1-15.

Goleman, D., Boyatzis, R., and McKee, A. (2002) Primal leadership, HBS Press, Boston.

Grahe, J. E. and Benrieri, F. J. (1999) The importance of nonverbal cues in judging rapport, Journal of Nonverbal Behavior, Vol. 23, No. 4, 253-269.

Gremier, D. D. and Gwinner, K. P. (2000) Customer-employee rapport in service relationships, Journal of Service Research, Vol. 3, No. 1, 82-104.

Groves, K. S. (2006) Leader emotional expressivity, visionary leadership, and organizational change, Leadership and Organization Development Journal, Vol. 27, No. 7, 566-583.

Halberstadt, A. G. (1986) Family socialization of emotional expression and nonverbalcommunication styles and skills, Journal of Personality and Social psychology, Vol. 51, 
No. $4,827-836$.

Hall, J. A., Roter, D. L., Blanch, D. C., \& Frankel, R. M. (2009) Observer-rated rapport in interactions between medical students and standardized patients. Patient Education and Counseling, Vol. 76, No. 3, 323-327.

Hartley, P. (1993) Interpersonal Communication. Routledge \& Kegan Paul.

Heath, C., Hindmarsh, J., \& Luff, P. (2010). Video in qualitative research. London, Sage Publication.

Henderson, L. S. (2004) Encoding and decoding communication competencies in project management - an exploratory study, International Journal of Project Management, Vol. 22, No. 6, 469-476.

Hofstede, G. and Hofstede, G. J. (2005) Cultures and organizations, $2^{\text {nd }}$ edition, McGrawHill, New York.

Holigrocki, R. J., Kaminski, P. L., \& Frieswyk, S. H. (1999) Introduction to the Parent-Child Interaction Assessment. Bulletin of the Menninger Clinic, Vol. 63, No. 3, 413-28.

Holt, G. D., Love, P. E. D. and Nesan, L. J. (2000). Employee empowerment in construction: an implementation model for process improvement, Team Performance Management: An International Journal, Vol. 6, No. 3/4, 47-51.

Ilies, R., Curşeu, P. L., Dimotakis, N., and Spitzmuller, M. (2013) Leaders' emotional expressiveness and their behavioural and relational authenticity: Effects on followers, European Journal of Work and Organizational Psychology, Vol. 22, No. 1, 4-14.

Ingersoll, B. (2010) Broader autism phenotype and nonverbal sensitivity: evidence for an association in the general population, Journal of Autism and Development Disorders, Vol. 40, No. 5, 590-598.

Iyer, K. C., and Jha, K. N. (2005) Factors affecting cost performance: evidence from Indian construction projects, International Journal of Project Management, Vol. 23, No. 4, 283295.

Jones, E. S. and LeBaron D. C. (2002) Research on the relationship between verbal and nonverbal communication: emerging integrations, Journal of communication, Vol. 52, No. 3, 499-521.

Ketrow, S. M. (1991), Nonverbal Communication and Client Satisfaction in ComputerAssisted Transactions, Management Communication Quarterly, Vol. 5, No. 2, 192-219.

Kloppenborg T. and Petrick, J. (1999) Leadership in project life cycle and team character development, Project Management Journal, Vol. 30, No. 2, 8-13.

Lewis, K. M. (2000) When leaders display emotion: how followers respond to negative emotional expression of male and female leaders, Journal of Organizational Behavior, No. 21, 221-234.

Lindebaum, D., and Cassell, C. (2012) A contradiction in terms? Making sense of emotional 
intelligence in a construction management environment, British Journal of Management, Vol. 23, No. 1, 65-79.

Lindebaum, D., and Jordan, P. J. (2012) Relevant but exaggerated: the effects of emotional intelligence on project manager performance in construction, Construction Management and Economics, Vol. 30, No. 7, 575-583.

Lloyd-Walker, B., and Walker, D. (2011) Authentic leadership for 21st century project delivery, International Journal of Project Management, Vol. 29, No. 4, 383-395.

Loosemore, M. and Galea, N. (2008) Genderlect and conflict in the Australian construction industry, Construction Management and Economics, Vol. 26, No. 2, 125-135.

Lopes, P. N., Salovey, P. and Cote, S. (2005) Emotion regulation abilities and the quality of social interaction, Brief Reports, Vol. 5, No. 1, 113-118.

Love, P., Edwards, D., Love, J., and Irani, Z. (2011) Champions of practice: context and habitus for unbounded learning in construction projects, Facilities, Vol. 29, No. 5/6, 193208.

Mäkilouko, M. (2004). Coping with multicultural projects: the leadership styles of Finnish project managers, International Journal of Project Management, Vol. 22, No. 5, 387396.

Mast, S. M., Jonas, K., Cronauer, K. and Darioly, A. (2012) On the importance of the superior's interpersonal sensitivity for good leadership, Journal of Applied Social Psychology, Vol. 42, No. 5, 1043-1068.

Mayer, J. D. and Salovey, P. (1997) What is emotional intelligence?, in Salovey, P. and Sluyter, D. (ed.), Emotional development and emotional intelligence: educational implications, Basic Books, New York.

Mayer, J. D., DiPaolo, M. T. and Salovey, P. (1990) Perceiving affective content in ambiguous visual stimuli: a component of emotional intelligence, Journal of Personality Assessment, Vol. 54, 772-81.

Mayer, J. D., Roberts, R. D. and Barsade, S. G. (2008) Human abilities: emotional intelligence, Annual Review of Psychology, 59, 507-36.

McDonald, J. D. (2008). Measuring personality constructs: The advantages and disadvantages of self-reports, informant reports and behavioural assessments. Enquire, Vol. 1, No. 1, 119.

Mintzberg, H. (1973) The nature of managerial work, Harper \& Row, New York.

Morris, P.W.G. (2013) Re-Constructing Project Management, Wiley-Blackwell, Chichester, UK.

Muller, R. and Turner, R. (2010a) Project-oriented leadership. Gower Publishing Ltd, Surrey.

Muller, R. and Turner, R. (2010b) Leadership competency profiles of successful project 
managers, International Journal of Project Management, Vol. 28, No. 5, 437-448.

Naoum, S. G. (2007) Dissertation research and writing for construction students, 2nd edition, Elsevier, Oxford.

Nicolini, D. (2002) In search of project chemistry, Construction Management and Economics, Vol. 20, No. 2, 167-177.

Parsons, H. M. (1974) What happened at Hawthorne? New evidence suggests the Hawthorne effect resulted from operant reinforcement contingencies, Science, Vo., 183, No. 4128, 922-932.

Patel, M. X., Doku, V., \& Tennakoon, L. (2003). Challenges in recruitment of research participants. Advances in Psychiatric Treatment, Vol. 9, No. 3, 229-238.

Patton, M. Q. (2005). Qualitative research. John Wiley \& Sons, UK.

Pescosolido, A. T. (2002) Emergent leaders as managers of group emotions, Leadership Quarterly, Vol. 13, No. 5, 583-599

Phua, F. T. (2013) Construction management research at the individual level of analysis: current status, gaps and future directions, Construction Management and Economics, Vol. 31, No. 2, 167-179

Pryke, S. D. and Smyth, H. (2006) Relationship approach to the management of projects, Blackwell, London.

Rajah, R., Song, Z. and Arvey, R. D. (2011) Emotionality and leadership: Taking stock of the past decade of research, The Leadership Quarterly, Vol. 22, No. 6, 1107-1119.

Riggio, R. E. (1986), Assessment of basic social skills, Journal of Personality and Social Psychology, Vo. 51, No. 3, 649-60.

Riggio, R. E. (2006) Nonverbal skills and abilities, in Manusov, V. L., The SAGE handbook of nonverbal communication, SAGE Publications.

Riggio, R. E. and Carney, D. C. (2003) Manual for the social skills inventory, $2^{\text {nd }}$ edition, Mind Garden, Mountain View.

Riggio, R. E. and Lee, J. (2007) Emotional and interpersonal competencies and leader development, Human Resource Management Review, Vol. 17, No. 4, 418-426.

Riggio, R. E. and Reichard, R. J. (2008) The emotional and social intelligences of effective leadership: an emotional and social skill approach, Journal of Managerial Psychology, Vol. 23, No. 2, 169-185.

Rosenthal, R., Hall, J. A., DiMatteo, M. R., Rogers, P. L. and Archer, D. (1979) The PONS Test, Baltimore.

Rosip, J. C. and Hall, J. A. (2004) Knowledge of nonverbal cues, gender and nonverbal decoding accuracy, Journal of Nonverbal Behavior, Vol. 28, No. 4, 267-286.

Rubin, R. S., Munz, D. C., and Bommer, W. H. (2005) Leading from within: the effects of emotion recognition and personality on transformational leadership behavior, Academy 
of Management Journal, Vol. 48, No. 5, 845-858.

Salovey, P. and Mayer, J. D. (1990) Emotional intelligence, Imagination, Cognition, and Personality, Vol. 9, No. 3, 185-211.

Salovey, P., Mayer, J. D. and Caruso, D. (2002) The positive psychology of emotional intelligence, in Snyder, C. R. and Lopez, S. J. (ed.), Handbook of positive psychology, Oxford University Press, New York.

Schyns, B. and Mohr, G. (2004) Nonverbal elements of leadership behaviour, German Journal of Human Resource Research Behavior, Vol. 18, No. 3, 71-95.

Scot, R. W. (1992) Organisations: rational, national and open systems, Prentice Hall.

Smith, G. R. (1999). Project leadership: why project management alone doesn't work. Hospital materiel management quarterly, Vol. 21, No. 1, 88-92.

Smithers, G.L. and Walker, D.H.T. (2000) The effect of the workplace on motivation and demotivation of construction professional, Construction Management and Economics, Vol.18, No. 7, 833-41.

Tett, R. P., Fox, K. E. and Wang, A. (2005) Development and validation of a self-report measure of emotional intelligence as a multidimensional trait domain, Personality and Social Psychology Bulletin, Vol. 31, No.7, 859-888.

Tickle-Degnen, L. and Rosenthal, R. (1987) Group rapport and nonverbal behavior in group processes and intergroup relation, Review of Personality and Social Psychology, 9, 11336.

Tickle-Degnen, L. and Rosenthal, R. (1990) The nature of rapport and its nonverbal correlates, Psychological Inquiry, Vol. 1, No. 4, 285-293.

Toor, S. R., Ofori, G. and Arain, F. M. (2007) Authentic leadership style and its implications in project management, Business Review, Vol. 2, No. 1, 31-55.

Troth, A. C., Jordan, P. J., Lawrance, S. A. and Tse, H. M. H. (2012) A multilevel model of emotional skills, communication performance, and task performance in teams, Journal of Organisational Behaviour, Vol. 33, No. 5, 700-722.

Tugrul, U. D., Ha, A., Reutiman, S., Hughes, B., Pathak, U., Bynum, W. and Bhatla, A. (2012) Exploring the communication breakdown in global virtual teams, International Journal of Project Management, Vol. 30, No. 2, 199-212.

Turner, J.R. and Müller, R. (2005). The project manager's leadership style as a success factor on projects: a literature review, Project Management Journal, Vol. 36, No. 1, 49-61.

Van Rooy, V. D. and Viswesvaran, C. (2004) Emotional intelligence: a meta-analytic investigation of predictive validity and nomological net, Journal of Vocational Behavior, Vol 65, No. 1, 71-95.

Weitz, B. A. (1981), Effectiveness in Sales Interactions: A Contingency Framework, Journal of Marketing, Vol. 45, No. 1, 85-103. 
Whitfield, J. (2012). Conflict in Construction. John Wiley \& Sons, UK.

Wilson, CR. V. and Morgan, L. B. (2007) Understanding power and rules of thumb for determining sample sizes, Tutorials in Quantitative Methods for Psychology, Vol. 3, No. 2, 43-50. 
Figure 1: The leader-follower chemistry model

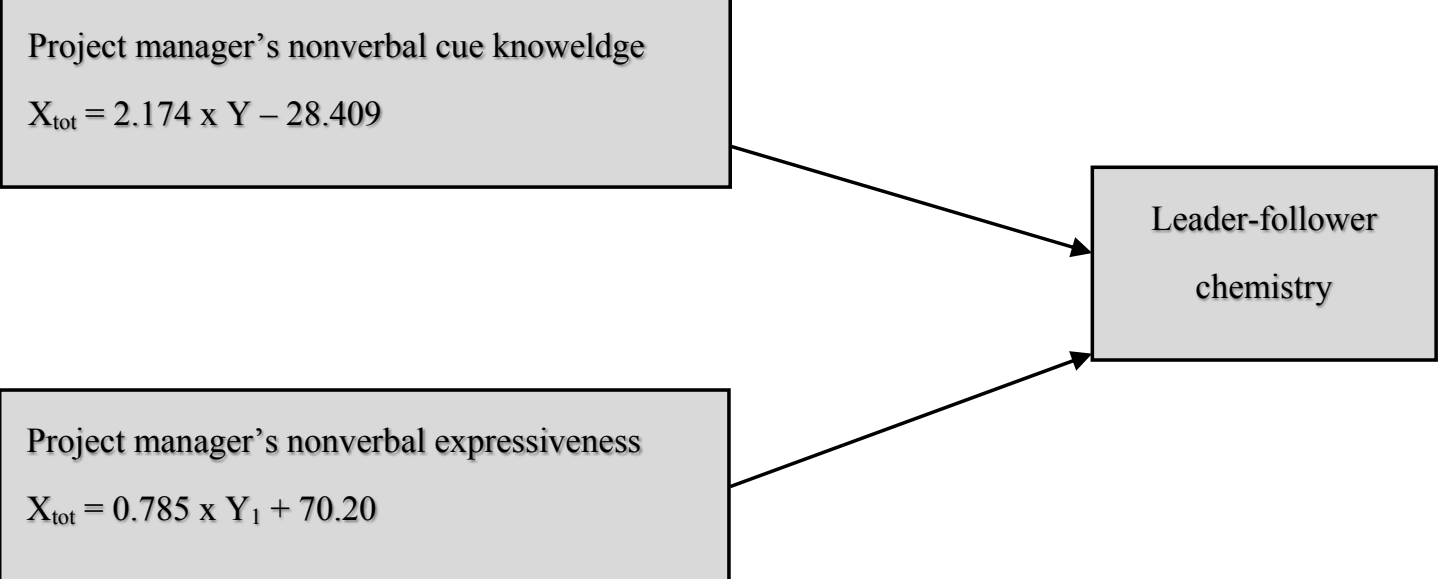


Table 1: Projects details and distribution of the research participants

\begin{tabular}{|c|c|c|c|c|c|c|c|}
\hline Project name & Project type & $\begin{array}{l}\text { Project } \\
\text { location }\end{array}$ & $\begin{array}{c}\text { Project } \\
\text { Manager }\end{array}$ & Client & Supervision & $\begin{array}{c}\text { Sub- } \\
\text { contractor }\end{array}$ & Total \\
\hline $\begin{array}{c}\text { Serbian } \\
\text { Electricity } \\
\text { Company }\end{array}$ & $\begin{array}{l}\text { The headquarter } \\
\text { reconstruction }\end{array}$ & Belgrade & $\begin{array}{c}1 \\
(12.5 \%)\end{array}$ & $\begin{array}{c}2 \\
(25 \%)\end{array}$ & $\begin{array}{c}2 \\
(25 \%)\end{array}$ & $\begin{array}{c}3 \\
(37.5 \%)\end{array}$ & $\begin{array}{c}8 \\
(100 \%)\end{array}$ \\
\hline Blue Horizon & New office building & Belgrade & $\begin{array}{c}1 \\
(16.67 \%)\end{array}$ & $\begin{array}{c}1 \\
(16.67 \%)\end{array}$ & $\begin{array}{c}1 \\
(16.67 \%)\end{array}$ & $\begin{array}{c}3 \\
(49.99 \%)\end{array}$ & $\begin{array}{c}6 \\
(100 \%)\end{array}$ \\
\hline Poletarac & $\begin{array}{l}\text { The school } \\
\text { reconstruction }\end{array}$ & Belgrade & $\begin{array}{c}1 \\
(16.67 \%)\end{array}$ & $\begin{array}{c}1 \\
(16.67 \%)\end{array}$ & $\begin{array}{c}2 \\
(33.33 \%)\end{array}$ & $\begin{array}{c}2 \\
(33.33 \%)\end{array}$ & $\begin{array}{c}6 \\
(100 \%)\end{array}$ \\
\hline Avala & $\begin{array}{l}\text { The dorm } \\
\text { reconstruction }\end{array}$ & Belgrade & $\begin{array}{c}1 \\
(9.09 \%)\end{array}$ & $\begin{array}{c}2 \\
(18.18 \%)\end{array}$ & $\begin{array}{c}3 \\
(27.27 \%)\end{array}$ & $\begin{array}{c}5 \\
(45.45 \%)\end{array}$ & $\begin{array}{c}11 \\
(100 \%)\end{array}$ \\
\hline Novi Sad & $\begin{array}{l}\text { The dorm } \\
\text { reconstruction }\end{array}$ & Novi Sad & $\begin{array}{c}1 \\
(25 \%)\end{array}$ & $\begin{array}{c}1 \\
(25 \%)\end{array}$ & $\begin{array}{c}1 \\
(25 \%)\end{array}$ & $\begin{array}{c}1 \\
(25 \%)\end{array}$ & $\begin{array}{c}4 \\
(100 \%)\end{array}$ \\
\hline Ratko Mitrovic & $\begin{array}{c}\text { New school } \\
\text { building }\end{array}$ & Belgrade & $\begin{array}{c}1 \\
(20 \%)\end{array}$ & $\begin{array}{c}1 \\
(20 \%)\end{array}$ & $\begin{array}{c}1 \\
(20 \%)\end{array}$ & $\begin{array}{c}2 \\
(40 \%)\end{array}$ & $\begin{array}{c}5 \\
(100 \%)\end{array}$ \\
\hline $\begin{array}{c}\text { Patris } \\
\text { Lumumba }\end{array}$ & $\begin{array}{l}\text { The dorm } \\
\text { reconstruction }\end{array}$ & Belgrade & $\begin{array}{c}1 \\
(16.67 \%)\end{array}$ & $\begin{array}{c}1 \\
(16.67 \%)\end{array}$ & $\begin{array}{c}1 \\
(16.67 \%)\end{array}$ & $\begin{array}{c}3 \\
(49.99 \%)\end{array}$ & $\begin{array}{c}6 \\
(100 \%)\end{array}$ \\
\hline $\begin{array}{c}\text { Corridors } \\
\text { Serbia }\end{array}$ & $\begin{array}{c}\text { The office building } \\
\text { reconstruction }\end{array}$ & Belgrade & $\begin{array}{c}1 \\
(14.28 \%)\end{array}$ & $\begin{array}{c}1 \\
(14.28 \%)\end{array}$ & $\begin{array}{c}3 \\
(42.86 \%)\end{array}$ & $\begin{array}{c}2 \\
(28.58 \%)\end{array}$ & $\begin{array}{c}7 \\
(100 \%)\end{array}$ \\
\hline US embassy & New US embassy & Belgrade & $\begin{array}{c}1 \\
(20 \%)\end{array}$ & / & / & $\begin{array}{c}4 \\
(80 \%)\end{array}$ & $\begin{array}{c}5 \\
(100 \%)\end{array}$ \\
\hline $\begin{array}{c}\text { Water systems } \\
\text { Serbia }\end{array}$ & $\begin{array}{c}\text { The office building } \\
\text { reconstruction }\end{array}$ & Vranje & $\begin{array}{c}1 \\
(25 \%)\end{array}$ & $\begin{array}{c}1 \\
(25 \%)\end{array}$ & $\begin{array}{c}1 \\
(25 \%)\end{array}$ & $\begin{array}{c}1 \\
(25 \%)\end{array}$ & $\begin{array}{c}4 \\
(100 \%)\end{array}$ \\
\hline 11 April & $\begin{array}{l}\text { The sport centre } \\
\text { reconstruction }\end{array}$ & Belgrade & $\begin{array}{c}1 \\
(33.33 \%)\end{array}$ & / & $\begin{array}{c}1 \\
(33.33 \%)\end{array}$ & $\begin{array}{c}1 \\
(33.33 \%)\end{array}$ & $\begin{array}{c}3 \\
(100 \%)\end{array}$ \\
\hline Cacak & $\begin{array}{l}\text { The dorm } \\
\text { reconstruction }\end{array}$ & Cacak & $\begin{array}{c}1 \\
(33.33 \%)\end{array}$ & / & $\begin{array}{c}1 \\
(33.33 \%)\end{array}$ & $\begin{array}{c}1 \\
(33.33 \%)\end{array}$ & $\begin{array}{c}3 \\
(100 \%)\end{array}$ \\
\hline Total & & & $\begin{array}{c}12 \\
(18 \%)\end{array}$ & $\begin{array}{c}11 \\
(16 \%)\end{array}$ & $\begin{array}{c}17 \\
(25 \%)\end{array}$ & $\begin{array}{c}28 \\
(41 \%)\end{array}$ & $\begin{array}{c}68 \\
(100 \%)\end{array}$ \\
\hline
\end{tabular}


Table 2: Research sample: number and rate of response by category

\begin{tabular}{cccc}
\hline Construction professionals & Questionnaires issued & Responses & \% Responses \\
\hline Client representatives & 16 & 11 & \\
& $(21.33 \%)$ & $(19.64 \%)$ & 68.75 \\
\hline Supervisors & 25 & 17 & 68 \\
\hline Sub-contractors & $(33.33 \%)$ & $(30.36 \%)$ & 82.35 \\
\hline Total & 34 & 28 & \\
\hline & $(45.34 \%)$ & $(50 \%)$ & 74.67
\end{tabular}


Table 3: Test of Nonverbal Cue Knowledge (TONCK) (Source: Rosip and Hall, 2004: 280)

This is a test of your knowledge of nonverbal communication. Some of the items on this test are fairly easy and some are very difficult. Just do your best and answer every item even if you feel you might be guessing.

\begin{tabular}{|c|c|c|}
\hline Question & True & False \\
\hline $\begin{array}{l}\text { The arrangement of objects in the environment is unlikely to influence how people } \\
\text { communicate. }\end{array}$ & & $X$ \\
\hline 2. You maintain greater interaction distances with unknown adults than with familiar adults. & $X$ & \\
\hline 3. Liars hesitate less during their speech than people who are telling the truth do. & & $X$ \\
\hline 4. People are likely to engage in self-touching when thinking (processing information). & $X$ & \\
\hline 5. Human beings can recognize the identity of a speaker with a high degree of accuracy. & $X$ & \\
\hline $\begin{array}{l}\text { 6eople put larger interpersonal distances between themselves and short people than with tall } \\
\text { people. }\end{array}$ & & $X$ \\
\hline 7. You maintain greater interaction distances with overweight people than with thin people. & $X$ & \\
\hline $\begin{array}{l}\text { 8. Romantic couples who experience more conflict and disagreement look at each other more } \\
\text { frequently than other couples. }\end{array}$ & & $X$ \\
\hline 9. Widening of the eyelids while speaking signifies emphasis on what was said. & $X$ & \\
\hline 10. When judging emotions from facial expressions, observers often confuse surprise and fear. & $X$ & \\
\hline 11. Someone who blinks a lot may be anxious. & $X$ & \\
\hline 12. The size of the pupil in a person's eye can influence interpersonal attraction to that person. & $X$ & \\
\hline 13. Rapid head nods are a signal to the speaker to finish quickly. & $X$ & \\
\hline 14. Embarrassment is associated with a distinctive set of facial behaviors. & $X$ & \\
\hline 15. The end of a sentence is usually followed by a pause in speech. & $X$ & \\
\hline $\begin{array}{l}\text { In a conversation speakers glance at their conversation partner at the end of a thought unit } \\
\text { or idea. }\end{array}$ & $X$ & \\
\hline 17. High foreheads are believed by lay people to be a sign of intelligence. & $X$ & \\
\hline $\begin{array}{l}\text { Shifts in the position of a person's body can signal the end but not the beginning of a } \\
\text { conversation. }\end{array}$ & & $X$ \\
\hline 19. Smiles are not reciprocated (returned) predictably. & & $X$ \\
\hline $\begin{array}{l}\text { 20. Observers can tell pretty well whether someone's facial expression reflects real or feigned } \\
\text { (faked) enjoyment. }\end{array}$ & $X$ & \\
\hline 21. In a conversation speakers glance to signal the other person to speak. & $X$ & \\
\hline 22. Thin lips are believed by lay people to be a sign of conscientiousness. & $X$ & \\
\hline 23. People are more likely to touch themselves while telling the truth than when lying. & & $X$ \\
\hline 24. Hand gestures can replace speech when we cannot or do not want to talk. & $X$ & \\
\hline 25. Someone's smile can affect your mood. & $X$ & \\
\hline 26. Blinking is not an indicator of physiological arousal. & & $X$ \\
\hline 27. In a conversation speakers glance at their partner to obtain feedback. & $X$ & \\
\hline
\end{tabular}


How much your face tends to show your emotions when you are not trying to do so, has

28. nothing to do with how accurate you will be at showing emotions when you make deliberate effort to do so.

29. Thick lips on women are believed by lay people to be a sign of sexiness.

30. Hand gestures are not used to regulate the flow of an interaction.

31. Men are more likely than women to pay attention to nonverbal cues that they can see,

31. compared to nonverbal cues in the voice.

32. Your seating position in a classroom is not related to your participation.

33. People from a lower socioeconomic background tend to score higher on judging the

33. meanings of nonverbal cues than people from higher socio- economic background.

34. Movements of the head and hands are infrequently used to accent the verbal message.

35. How long you wait before speaking when it is your turn doesn't seem to distinguish people who are high and low in social anxiety.

36. In a conversation speakers glance to see if the audience will let them continue.

37. To tell if someone is truly feeling amusement or enjoyment, you need to look at his or her eyes.

38. A speaker's age can be estimated fairly accurately from his or her voice.

39. In a dimly lit room people tend to sit farther apart.

40. Social anxiety is related to higher levels of gazing at another person during conversation.

41. Men are better at judging facial cues than women are.

42. A speaker's sex cannot be guessed from his or her voice.

43. Increased facial movements are associated with anxiety.

44. Under stress, the pitch of the human voice gets lower.

45. Gaze can regulate the flow of communication.

46. Pitch is not used to differentiate male and female voices.

47. Males are better at decoding nonverbal behavior than females.

48. Errors while speaking, such as stutters, repetitions, and omissions, are more common for men than for women.

49. Gaze can express emotions.

50. Anger in the voice is revealed by a decrease in speech rate.

51. Parts of the face are used to open and close channels of communication.

52. Females react favorably to strangers approaching them from the side.

53. Females gaze more at their partner when farther away from their partners than when they are closer.

54. The pupil of your eye dilates when you are engaged in a task that requires mental effort.

55. Males react favorably to strangers approaching from the front.

56. You gaze more when you are interested in the reactions of your audience.

57. Lowered brows are not a common sign of an angry feeling.

58. When we want to speak we sometimes open our mouths in readiness to talk.

59. There is no difference in how much males and females gaze at a partner during an interaction.

60. You gaze less when you like or love your partner.

\begin{tabular}{|l|l|}
\hline & $X$ \\
\hline & $X$ \\
\hline
\end{tabular}


61. The eyebrow flash (raising and lowering of the eyebrow) is found in greeting rituals and signals desire to interact.

62. Interpersonal attraction is not a predictor of how close people stand to each other.

63. You gaze less when you want to influence or dominate.

64. Among high school students, girls are more accurate than boys in judging the meanings of face, body, and vocal nonverbal cues.

65. Smiles can signal attentiveness and involvement.

66. In conversation, a more dominant person is likely to show relatively more gazing while speaking than while listening, compared to a less dominant person.

67. Women are gazed at less than males.

68. Among adults, females touch others more than males do.

69. Shy people gaze more.

70. Sadness is not easily identified from a person's voice.

71. People with high affiliative needs tend to glance and return glances more often.

72. Side positions at tables convey leadership.

73. You gaze more when you want to be included.

74. Joy is not easily identified from a person's voice.

75. When you want to continue talking in a conversation you are likely to pause more.

76. How close you sit to another person is not a function of how interpersonally close your relationship is.

77. Anger is not easily identified from a person's voice.

78. We raise or drop pitch at the end of a comment to signal the end of a speaking turn.

79. People approach both high and low status others more closely than they approach equal status others.

80. People depart more hastily from a male invading their space than from a female invading their space.

81. You gaze more at strangers when you are physically close to them.

$X$

Note: The correct answer is marked for each item. 
Table 4: Body Movement Checklist (Source: Bull, 1983)

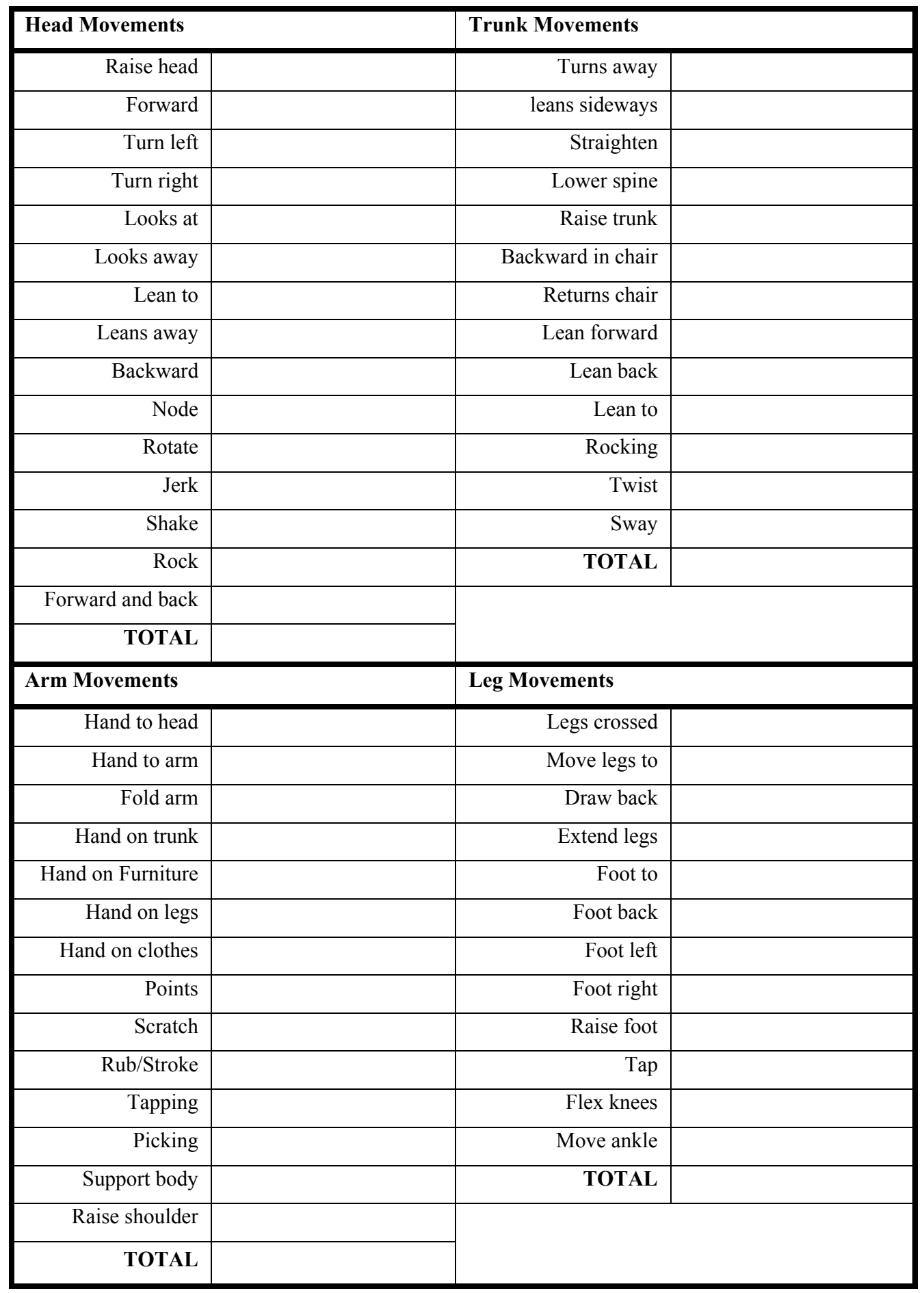


Table 5: Facial Movement Checklist (Source: Ekman and Freisen, 1978)

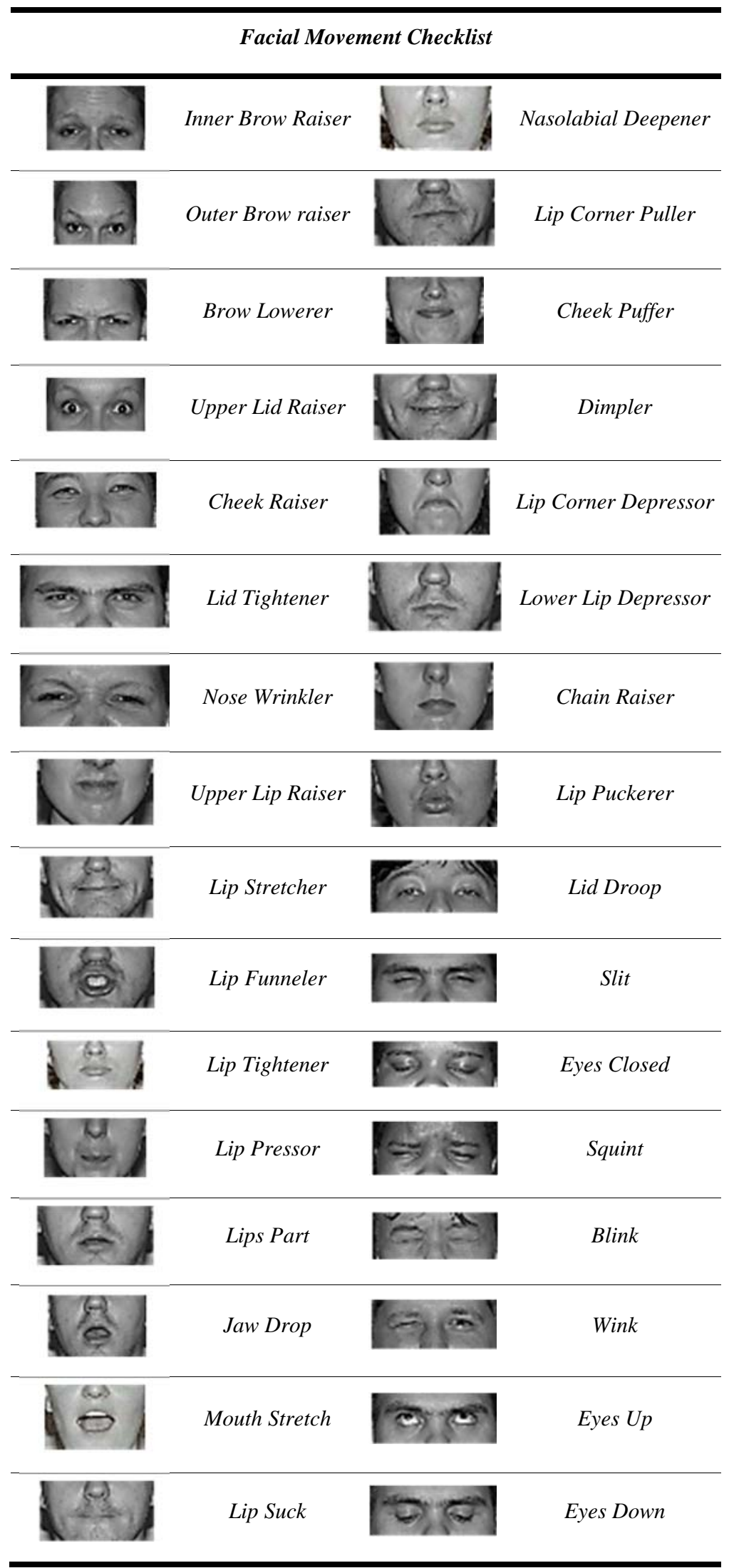


Table 6: The 18-item Rapport Questionnaire (Source: Bernieri, et al., 1994)

Please rate the interaction you have just experienced between you and the project manager on each of the characteristics listed:

\begin{tabular}{|c|c|c|c|c|c|c|c|c|c|c|}
\hline \multicolumn{2}{|c|}{ This interaction was: } & \multicolumn{7}{|c|}{ Not at all } & \multicolumn{2}{|c|}{ Extremely } \\
\hline 1 & Well-coordinated & 0 & 1 & 2 & 3 & 4 & 5 & 6 & 7 & 8 \\
\hline 2 & Boring & 0 & 1 & 2 & 3 & 4 & 5 & 6 & 7 & 8 \\
\hline 3 & Cooperative & 0 & 1 & 2 & 3 & 4 & 5 & 6 & 7 & 8 \\
\hline 4 & Harmonious & 0 & 1 & 2 & 3 & 4 & 5 & 6 & 7 & 8 \\
\hline 5 & Satisfying & 0 & 1 & 2 & 3 & 4 & 5 & 6 & 7 & 8 \\
\hline 6 & Comfortably paced & 0 & 1 & 2 & 3 & 4 & 5 & 6 & 7 & 8 \\
\hline 7 & Cold & 0 & 1 & 2 & 3 & 4 & 5 & 6 & 7 & 8 \\
\hline 8 & Awkward & 0 & 1 & 2 & 3 & 4 & 5 & 6 & 7 & 8 \\
\hline 9 & Engrossing & 0 & 1 & 2 & 3 & 4 & 5 & 6 & 7 & 8 \\
\hline 10 & Focused & 0 & 1 & 2 & 3 & 4 & 5 & 6 & 7 & 8 \\
\hline 11 & Involving & 0 & 1 & 2 & 3 & 4 & 5 & 6 & 7 & 8 \\
\hline 12 & Intense & 0 & 1 & 2 & 3 & 4 & 5 & 6 & 7 & 8 \\
\hline 13 & Friendly & 0 & 1 & 2 & 3 & 4 & 5 & 6 & 7 & 8 \\
\hline 14 & Active & 0 & 1 & 2 & 3 & 4 & 5 & 6 & 7 & 8 \\
\hline 15 & Positive & 0 & 1 & 2 & 3 & 4 & 5 & 6 & 7 & 8 \\
\hline 16 & Dull & 0 & 1 & 2 & 3 & 4 & 5 & 6 & 7 & 8 \\
\hline 17 & Worthwhile & 0 & 1 & 2 & 3 & 4 & 5 & 6 & 7 & 8 \\
\hline 18 & Slow & 0 & 1 & 2 & 3 & 4 & 5 & 6 & 7 & 8 \\
\hline
\end{tabular}


Table 7: Descriptive statistics for D2 data set

\begin{tabular}{|c|c|c|c|c|c|c|c|c|c|c|c|c|c|c|c|c|c|c|c|c|}
\hline & $\mathrm{X} 1$ & $\mathrm{X} 2$ & X3 & $\mathrm{X} 4$ & $\mathrm{X} 5$ & X6 & X7 & $\mathrm{X} 8$ & X9 & $\mathrm{X} 10$ & $\mathrm{X} 11$ & $\mathrm{X} 12$ & X13 & X14 & X15 & $\mathrm{X} 16$ & $\mathrm{X} 17$ & $7 \mathrm{X} 18$ & X19 & $\mathrm{Y}$ \\
\hline Min. & 1.33 & 0.20 & 1.33 & 0.33 & 1.33 & 0.67 & 1.20 & 0.43 & 1.33 & 1.33 & 1.00 & 1.33 & 3.33 & 1.00 & 2.33 & 1.00 & 1.33 & 1.29 & -5.33 & 34.00 \\
\hline Max. & 6.86 & 7.00 & 6.57 & 6.29 & 6.43 & 6.50 & 6.00 & 6.00 & 6.57 & 7.50 & 6.57 & 6.50 & 7.00 & 6.50 & 6.50 & 6.00 & 6.80 & 5.00 & 62.80 & 65.00 \\
\hline Mean & 5.02 & 2.46 & 4.92 & 4.13 & 4.68 & 4.47 & 2.98 & 2.36 & 4.59 & 5.13 & 5.03 & 4.69 & 5.56 & 4.84 & 5.29 & 3.03 & 5.26 & 2.71 & 40.69 & 54.08 \\
\hline SD & 1.57 & 1.92 & 1.48 & 1.71 & 1.52 & 1.76 & 1.54 & 1.65 & 1.56 & 1.49 & 1.51 & 1.53 & 0.94 & 1.60 & 1.21 & 1.90 & 1.59 & 1.33 & 20.64 & 8.63 \\
\hline
\end{tabular}
Sample size N $=12$ 
Table 8: 2-tailed Pearson product moment correlation results for study 1

\begin{tabular}{|llcc|}
\hline & & X19 & Y \\
\hline X19 & Pearson Correlation & 1 &, $722^{* *}$ \\
Y & Pearson Correlation &, $722^{* *}$ & 1 \\
\hline
\end{tabular}

** Correlation is significant at the 0.01 level (2-tailed). Sample size $\mathrm{N}=56$ 
Table 9: Descriptive statistics for D4 data set

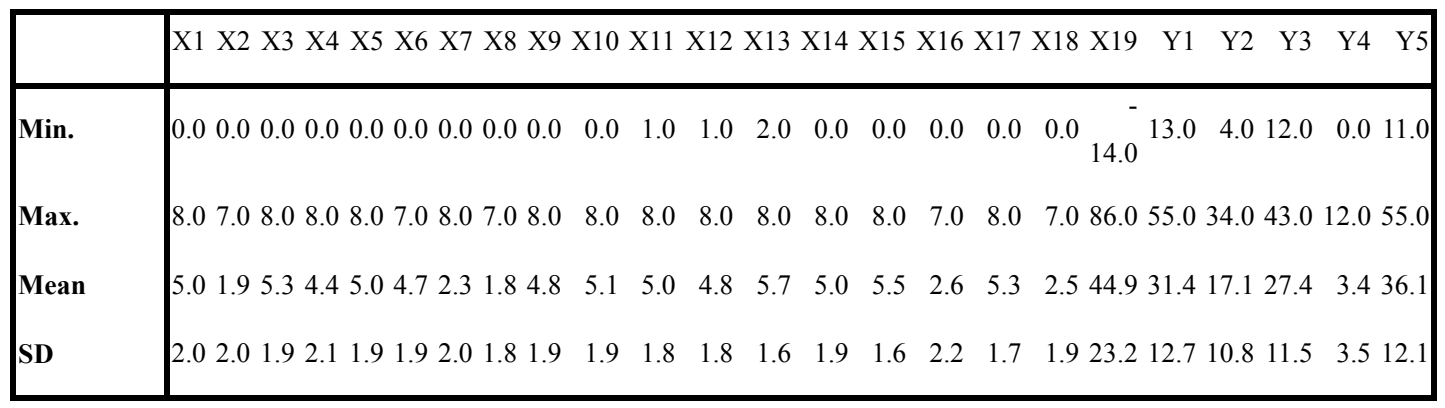

Sample size N=49 
Table 10: 2-tailed Pearson product moment correlation results for study 2

\begin{tabular}{|c|cccccc|}
\hline & $\mathrm{X} 19$ & $\mathrm{Y} 1$ & $\mathrm{Y} 2$ & $\mathrm{Y} 3$ & $\mathrm{Y} 4$ & $\mathrm{Y} 5$ \\
\hline $\mathrm{X} 19$ & 1 &, 528 &, 460 &, 401 &, 364 &, 409 \\
$\mathrm{Y} 1$ &, $528^{* *}$ & 1 &, $766^{* *}$ &, $736^{* *}$ &, $609^{* *}$ &, $639^{* *}$ \\
$\mathrm{Y} 2$ &, $460^{* *}$ &, $766^{* *}$ & 1 &, $850^{* *}$ &, $504^{* *}$ &, $788^{* *}$ \\
$\mathrm{Y} 3$ &, $401^{* *}$ &, $736^{* *}$ &, $850^{* *}$ & 1 &, $405^{* *}$ &, $819^{* *}$ \\
$\mathrm{Y} 4$ &, $364^{* *}$ &, $609^{* *}$ &, $504^{* *}$ &, $405^{* *}$ & 1 &, $316^{*}$ \\
$\mathrm{Y} 5$ &, $409^{* *}$ &, $639^{* *}$ &, $788^{* *}$ &, $819^{* *}$ &, $316^{*}$ & 1 \\
\hline
\end{tabular}

*Correlation is significant at the level 0.05 (2-tailed)

**Correlation is significant at the level 0.01 (2-tailed)

Sample size $\mathrm{N}=56$ 
Table 11: Pearson correlation matrix for study 3

\begin{tabular}{|c|cccccc|}
\hline & Y & Y1 & Y2 & Y3 & Y4 & Y5 \\
\hline Y & 1.00 & & & & & \\
Y1 & $0.752^{* *}$ & 1.00 & & & & \\
Y2 & $0.750^{* *}$ & $0.766^{* *}$ & 1.00 & & & \\
Y3 & $0.628^{* *}$ & $0.736^{* *}$ & $0.850^{* *}$ & 1.00 & & \\
Y4 & $0.568^{* *}$ & $0.609^{* *}$ & $0.504^{* *}$ & $0.405^{* *}$ & 1.00 & \\
Y5 & $0.622^{* *}$ & $0.639^{* *}$ & $0.788^{* *}$ & $0.819^{* *}$ & $0.316^{*}$ & 1.00 \\
\hline
\end{tabular}

*Correlation is significant at the 0.05 level (2-tailed).

$* *$ Correlation is significant at the 0.01 level (2-tailed).

Sample size $\mathrm{N}=56$ 
Table 12: "ENTER" regression between Xtot and Y (emotional sensitivity)

\begin{tabular}{|c|c|c|c|c|c|c|}
\hline & \multirow{2}{*}{ Model } & \multicolumn{2}{|c|}{ Unstandardized Coefficients } & $\begin{array}{l}\text { Standardized } \\
\text { Coefficients }\end{array}$ & \multirow{2}{*}{$\mathrm{t}$} & \multirow{2}{*}{ Sig. } \\
\hline & & $\mathrm{B}$ & Std. Error & Beta & & \\
\hline \multirow{2}{*}{1} & (Constant) & $-28,409$ & 15,841 & & $-1,793$ & ,079 \\
\hline & Y1 & 2,174 & 284 & ,722 & 7,663 & ,000 \\
\hline
\end{tabular}

a. Dependent Variable: X19 
Table 13: multiple regression between Xtot and Y1-5 (emotional expressiveness)

\begin{tabular}{|c|c|c|c|c|c|c|}
\hline \multirow{2}{*}{\multicolumn{2}{|c|}{ Model }} & \multicolumn{2}{|c|}{ Unstandardized Coefficients } & \multirow{2}{*}{$\begin{array}{c}\text { Standardized } \\
\text { Coefficients } \\
\text { Beta } \\
\end{array}$} & \multirow[b]{2}{*}{$\mathrm{t}$} & \multirow[b]{2}{*}{ Sig. } \\
\hline & & B & Std. Error & & & \\
\hline \multirow[t]{2}{*}{1} & (Constant) & 70,203 & 5,443 & & 12,897 &, 000 \\
\hline & Y1 & ,785 & ,172 & ,528 & 4,572 &, 000 \\
\hline
\end{tabular}

a. Dependent Variable: X19

Excluded Variables ${ }^{b}$

\begin{tabular}{|c|c|c|c|c|c|c|}
\hline \multirow{2}{*}{\multicolumn{2}{|c|}{ Model }} & \multirow{2}{*}{ Beta In } & \multirow[b]{2}{*}{$\mathrm{t}$} & \multirow[b]{2}{*}{ Sig. } & \multirow[b]{2}{*}{ Partial Correlation } & Collinearity Statistics \\
\hline & & & & & & Tolerance \\
\hline \multirow[t]{4}{*}{1} & Y2 &, $135^{\mathrm{a}}$ & ,746 & ,459 & ,102 & ,414 \\
\hline & $\mathrm{Y} 3$ &, $027^{\mathrm{a}}$ &, 159 &, 874 & ,022 & ,459 \\
\hline & Y4 &, $067^{\mathrm{a}}$ & ,457 & ,649 & ,063 & ,629 \\
\hline & Y5 &, $121^{\mathrm{a}}$ & 805 & 424 &, 110 & ,591 \\
\hline
\end{tabular}

a. Predictors in the Model: (Constant), $Y 1$

b. Dependent Variable: X19 